\title{
Meteorological Annual Report for 1997
}

by

C. H. Hunter

Westinghouse Savannah River Company

Savannah River Site

Aiken, South Carolina 29808

O. Minyard

This paper was prepared in connection with work done under the above contract number with the U. S. Department of Energy. By acceptance of this paper, the publisher and/or recipient acknowledges the U. S. Government's right to retain a nonexclusive, royalty-free license in and to any copyright covering this paper, along with the right to reproduce and to authorize others to reproduce all or part of the copyrighted paper. 


\section{DISCLAIMER}

This report was prepared as an account of work sponsored by an agency of the United States Government. Neither the United States Government nor any agency thereof, nor any of their employees, makes any warranty, express or implied, or assumes any legal liability or responsibility for the accuracy, completeness, or usefulness of any information, apparatus, product, or process disclosed, or represents that its use would not infringe privately owned rights. Reference herein to any specific commercial product, process, or service by trade name, trademark, manufacturer, or otherwise does not necessarily constitute or imply its endorsement, recommendation, or favoring by the United States Government or any agency thereof. The views and opinions of authors expressed herein do not necessarily state or reflect those of the United States Government or any agency thereof.

This report has been reproduced directly from the best available copy.

Available to DOE and DOE contractors from the Office of Scientific and Technical Information, P.O. Box 62, Oak Ridge, TN 37831; prices available from (615) 576-8401.

Available to the public from the National Technical Information Service, U.S. Department of Commerce, 5285 Port Royal Road, Springfield, VA 22161. 


\section{DISCLAIMER}

Portions of this document may be illegible in electronic image products. Images are produced from the best available original document. 


\section{ANNUAL METEOROLOGICAL REPORT FOR 1997 (U)}

Charles H. Hunter

Olivia Minyard

Approval

Date

R. P. Addis, Manager, Atmospheric Technology Group

QDene Date $11-10-98$

A. L. Boni, Manager, Nonproliferation Technologies Section

November 1998

Westinghouse Savannah River Company

Savannah River Site

Aiken, SC 29808

Prepared for the Department of Energy under contract no. DE-AC09-89SR18035 


\section{Executive Summary}

An analysis of meteorological data collected at the Savannah River Site (SRS) in 1997 shows that overall weather conditions for the year were relatively cool and wet. The average temperature for 1997 was $63.7^{\circ} \mathrm{F}$ which is about $1^{\circ} \mathrm{F}$ below the annual average for the 30-year period 1968-97. June 1997 had the lowest average temperature of any June in the 34 years for which temperature records are available at SRS ; moreover, the average temperature for the summer months (June, July, and August) was the third lowest for any summer on record. Conversely, the average temperature for March 1997 was the highest for any March in the 34-year record. Temperature extremes for 1997 ranged from a minimum of $18.6^{\circ} \mathrm{F}$ on January 18 to a maximum of $99.1^{\circ} \mathrm{F}$ on August 15.

Wet weather during the last three months of the year was due to the development of a strong El Nino event (NOAA, 1998). Total rainfall for December 1997, 10.19 inches, was the highest for a December in the 46 year period of record for precipitation. Monthly rainfall was above average each month except March, May, and August. The greatest 24-hour rainfall during the year was 2.82 inches on December 24. Daily rainfall in excess of 2 inches occurred on April 28, June 28, and September 25. No snow was recorded.

The annual average wind speed at the Central Climatology meteorology tower near $\mathrm{N}$ Area was $5.8 \mathrm{mph}$ which is very nearly equal to the average wind speed at that station for the 7-year period 1991-97. The 1997 data also showed a slightly higher frequency of west to northwest winds and a slightly lower frequency of northeast winds than was observed in the 5-year period 1992-96. A winter storm which developed over the Mid-Atlantic States March 30-31 produced the most notable period of sustained strong winds. Daily and 15-minute average wind speeds of 15.3 miles per hour ( $\mathrm{mph}$ ) and $25.1 \mathrm{mph}$, respectively, were recorded at Central Climatology.

Monthly average relative humidity for the year was lowest during the spring months (52 percent in April) and highest in the summer and fall (79 percent in October). The average relative humidity for the year was 70 percent and the average daily minimum relative humidity, which typically occurs during the afternoon, was 46 percent.

No tropical weather systems affected the SRS region in 1997. Tropical weather activity in the Atlantic basin during the year was below average due to the effects of the developing El Nino (NOAA, 1998)

Summary plots of 1997 daily minimum/maximum temperature, 24-hour total 
precipitation, daily minimum relative humidity, and daily average wind speed are shown in Figure 1.

\section{Introduction}

\section{General SRS Climate}

The southeastern U.S. has a humid subtropical climate characterized by relatively short, mild winters and long, warm, and humid summers (Oliver and Fairbridge, 1987).

Summer-like weather conditions typically last from May through September, when the area is under the influence of the western extension of the semipermanent Atlantic subtropical anticyclone (i.e. the 'Bermuda' high). Winds in summer are light and cold fronts generally remain well north of the area. Daily high temperatures during the summer months exceed $90^{\circ} \mathrm{F}$ on more than half of all days on the average. The persistent heat and humidity often result in scattered afternoon and evening thunderstorms.

The influence of the Bermuda high begins to wane during the fall, resulting in lower humidity and more moderate temperatures. Average rainfall during the fall is usually the least of the four seasons.

The weather is quite changeable during the winter months, as mid-latitude low pressure systems and fronts migrate through the region. Weather conditions frequently alternate between warm, moist, subtropical air from the Gulf of Mexico region and cool, dry polar air. The Appalachian Mountains to the north and northwest of the SRS help to moderate the extremely cold temperatures associated with occasional outbreaks of Arctic air. As a result, less than one-third of winter days have minimum temperatures below freezing on the average and days with temperatures below $20^{\circ} \mathrm{F}$ are infrequent. Measurable snowfall is rare.

Spring is characterized by a higher frequency of occurrence of tornadoes and severe thunderstorms than the other seasons. Although spring weather is somewhat windy, temperatures are mild and the humidity is relatively low.

Detailed descriptions of the climate of the SRS are contained in Hunter (1989), Hoel (1984), and Weber (1993).

\section{SRS Meteorological Monitoring Program}

The Atmospheric Technologies Group (ATG) of SRTC collects, archives, and analyzes basic meteorological data supporting a variety of activities at SRS 
including the design, construction, and operation of nuclear and non-nuclear facilities, emergency response, environmental compliance, resource management, and environmental research.

The ATG maintains a network of eight 200-foot meteorological observation towers located at A, C, D, F, H, K, L, and P areas. Additional meteorological instrumentation is located at the Central Climatology facility near $\mathrm{N}$-area, which includes a 200-foot observation tower, and on the 1000-foot WJBF-TV tower near Beech Island, SC. Measurements of wind speed, direction, turbulence, air temperature, and dew point temperature are taken at a height of 200 feet above ground on all of the site towers. Identical measurements are made on the Central Climatology tower at heights of 13, 58, 116, and 200 feet. Additional measurements conducted at Central Climatology consist of precipitation, evaporation, solar radiation, barometric pressure, and soil temperature. At the WJBF-TV tower, measurements of wind speed, direction, turbulence, and air temperature are recorded at seven levels through 1000 feet. A measurement from each sensor in the network is taken at 1.5-second intervals by a centrally located computer. Fifteen minute averages and standard deviations are computed and stored in a relational database.

Additional measurements of temperature and relative humidity are taken with a hygrothermograph mounted in a standard National Weather Service 'cotton region' instrument shelter adjacent to Building 773-A. Data from the hygrothermograph are continuously output to a strip chart recorder. Daily maximum and minimum values of temperature and relative humidity are manually extracted from the strip charts and entered into a computer database. Daily precipitation is measured with a plastic wedge rain gauge located adjacent to the instrument shelter. Rainfall measurements are taken once per day, usually around 9 AM. Data collection at or near the 773-A site has been conducted since 1952 and the data have been used extensively in basic descriptions of the SRS climate. The data recorded at this site are subject to a manual quality control inspection to ensure the reasonableness of the data; nevertheless, some errors may be present in the data record.

A map showing each of the measurement locations is given in Attachment A. Parker and Addis (1994) and Kurzeja (1993) provide detailed descriptions of the ATG meteorological monitoring facilities and instrumentation.

\section{Data Sources for the 1997 Annual Meteorological Report}

This report contains tabular and graphical summaries of data collected during 1997 for temperature, precipitation, relative humidity, wind, barometric pressure, and solar radiation. Most of these data were collected at the Central 
Climatology facility. (Relative humidity is calculated from measurements of dew point temperature.) Summaries of temperature and relative humidity were generated with data from the lowest level of measurement at the Central Climatology tower (13 feet above ground). Wind speed summaries were generated with data from the second measurement level ( 58 feet above ground). Wind speed measurements from this level are believed to best represent open, well-exposed areas of the Site. In addition, seasonal and annual summaries of the joint frequency of occurrence of wind direction sector by wind speed category (i.e. wind roses) are provided for the Central Climatology tower (200foot level only) and each of the eight area towers.

Long-term averages and extremes of temperature, precipitation, and relative humidity are based on data collected from the 773-A instrument shelter through 1994 and the Central Climatology from 1995 to the present.

Valid data recovery for the onsite monitoring towers in 1997 is summarized below:

Tower Data Recovery (\%)

$\begin{array}{lll}\text { Area Towers: } & \text { A-Area } & 93.8 \\ & \text { C-Area } & 96.3 \\ & \text { D-Area (61m) } & 98.1 \\ & \text { F-Area } & 98.5 \\ & \text { H-Area } & 95.6 \\ & \text { K-Area } & 97.8 \\ & \text { L-Area } & 96.0 \\ & \text { P-Area } & 97.2 \\ & & \\ \text { Central Climatology: } & \text { 61-m } & 91.9 \\ & \text { 36-m } & 91.5 \\ & \text { 18-m } & 91.1 \\ & \text { 4-m } & 96.8\end{array}$

\section{Data Summaries}

\section{Overview}

Annual and monthly averages and extremes for each of the meteorological variables summarized this report are given in Table 1 . Plots of daily minimum and maximum temperatures, 24-hour total precipitation, daily minimum relative humidity, and daily average wind speed are shown in Figure 1.

The first three months of the year were dominated by a persistent presence of the 
south Atlantic subtropical high over Florida. This pattern produced frequent periods of relatively warm, moist southwesterly airflow over the southeast U.S. Above average temperatures were observed at SRS in January $\left(+2.3^{\circ} \mathrm{F}\right)$, February $\left(+3.6^{\circ} \mathrm{F}\right)$, and March $\left(+6.5^{\circ} \mathrm{F}\right)$. The average temperature for March $1997\left(63.6^{\circ} \mathrm{F}\right)$ was the warmest of any March in the 34 years for which temperature records are available at SRS. Temperatures below freezing were observed only 3 days in February and March, well below the average of 12 'freezing' days for these months.

A temporary weakening of the subtropical high in mid-January brought Arctic high pressure into the region on two occasions. The coldest day of the year occurred on January 18 when the morning. low dropped to $18.6^{\circ} \mathrm{F}$, following a high temperature of only $36^{\circ} \mathrm{F}$ the previous day.

A winter storm which developed over the Mid-Atlantic States March 30-31 produced the most notable period of sustained strong winds. Daily and 15minute average wind speeds of 15.3 miles per hour ( $\mathrm{mph}$ ) and $25.1 \mathrm{mph}$, respectively, were recorded at Central Climatology. Otherwise, winds were relatively light during the winter period as the persistent subtropical high kept winter storms well north of the area.

Frequent periods of relatively cool weather affected much of the eastern U.S. during the remainder of 1997 (NOAA, 1998). For April through August, the cool weather was the result of re-development of a negative phase North Atlantic oscillation (NAO). The NAO is an unusual hemispheric circulation pattern which produces an intensification and southward migration of the polar jet stream across central and eastern North America (NOAA, 1997).

Observed temperatures for April, May, and June were all more than three degrees below their respective 30-year averages. Moreover, the June 1997 average of $74.0^{\circ} \mathrm{F}\left(4.7^{\circ} \mathrm{F}\right.$ below average) was the lowest for any June in the 34 year record and the average temperature for the summer months of 1997 (June, July, and August) was the third lowest for any summer on record.

A temporary repositioning of the 'Bermuda' high over the southeast U.S. brought relatively hot weather to SRS on two occasions: late June and mid August. The hottest temperature of the year, $99.1^{\circ} \mathrm{F}$ was recorded August 15 . High temperatures during the summer reached $90^{\circ} \mathrm{F}$ or higher on 50 days, which is about one-third less than the annual average total of 76 days.

Cool, cloudy, and increasingly wet weather over the last three months of the year was were the result of storminess associated with a strengthening subtropical jet stream over the southern half on the U.S. The subtropical jet, characterized by strong west to east winds aloft, becomes very pronounced during the Northern 
Hemisphere cool season when mature El Nino conditions are present in the eastern Pacific. Above normal rainfall was observed during September through December. Furthermore, total rainfall in December 1997 (10.12 inches) was the greatest for any December in the 46 years of precipitation records at SRS. The greatest 24-hour rainfall for the year, 2.82 inches, occurred on December 24.

\section{Detailed Summaries by Variable}

\section{Temperature}

Figure 2 shows a plot of 1997 daily minimum and maximum temperature. Annual and monthly average temperatures for the 30-year period 1968-97 are summarized in Table 2 and plotted in Figures 3 and 4.

Temperatures for 1997 ranged from a minimum of $18.6^{\circ} \mathrm{F}$, observed on the morning of January 18 , to a maximum of $99.1^{\circ} \mathrm{F}$, observed on the afternoon of August 15. The average temperature for 1997 was $63.7^{\circ} \mathrm{F}$ which is about $1^{\circ} \mathrm{F}$ below the average for the 30-year period 1968-97.

July was the warmest month of the year with an average daily maximum of $90.3^{\circ} \mathrm{F}$ and an average daily minimum of $70.2^{\circ} \mathrm{F}$; December was the coldest month with an average daily high of $55.4^{\circ} \mathrm{F}$ and an average daily low of $38.5^{\circ} \mathrm{F}$. Monthly average temperatures for 1997 were below their respective 30-year averages for each month except January, February and March. March was particularly warm with an average temperature that was the highest of any March in the 34 years for which temperature records are available. Conversely, the average temperature for June was the lowest for any June on record. The months of April, May, and November also were particularly cool with monthly average temperatures generally more than $3^{\circ} \mathrm{F}$ below their respective 30 -year averages. High temperatures greater than $90^{\circ} \mathrm{F}$ were observed on only 50 days during the year (see Fig. 5). The average number of days per year with temperatures equal to or exceeding $90^{\circ} \mathrm{F}$ is 74 . Nearly half of the total 'hot' days for 1997 occurred in July (19 days). Minimum temperatures below $32^{\circ} \mathrm{F}$ were observed on 26 days, which is less than the 30 -year mean of 37 'freeze days' per year.

\section{Precipitation}

Daily precipitation for 1997 is summarized graphically in Figure 6. Annual and monthly rainfall since 1968 is summarized in Table 3 and plotted in figures 7 and 
8 , respectively.

Rainfall of 0.01 inches or more was observed on 112 days during the year. The maximum 24-hour rainfall was 2.82 inches on December 24. Daily rainfall in excess of 2 inches also occurred on April 28, June 18, and September 25.

Total precipitation for 1997 was 62.4 inches, which is about 12.4 inches above the average annual total for the 30-year period 1968-97. Annual rainfalls greater than the 1997 total has occurred only twice in the 46 years for which precipitation records are available (1971 and 1964). Above average rainfall was recorded in every month except March, May, and August. The total rainfall for December 1997, 10.12 inches, was the highest for any December over the 46 years of record.

\section{Relative Humidity}

A plot of daily minimum and maximum relative humidity is shown in Figure 9. Annual average relative humidity and monthly average minimum relative humidity, is plotted in figures 10 and 11 , respectively.

The lowest relative humidity observed in 1997 was 14 percent on April 1, associated with a strong high pressure over the southeast US. Daily minimum relative humidity was frequently less than 30 percent during the winter and spring months, but rarely below 40 percent during the summer and fall.

The average relative humidity for 1997 was 70 percent, slightly higher than the average value of 68 percent for the 30-year period 1968-97. The average daily maximum for 1997 was 88.4 percent and the average daily minimum was 43.4 percent. Monthly average relative humidity ranged from 52.5 percent in April to 79.2 percent in October. The monthly averages of daily minimum relative humidity in 1997 were below 30-year averages during the spring as high pressure dominated the area, and greater than the 30-year averages during the early to mid summer period and throughout a relatively wet fall.

\section{Wind}

A plot of daily average wind speed for 1997 is shown in Figure 12. The annual average wind speed (surface) was $5.8 \mathrm{mph}$, which is very nearly equal to an average of $5.7 \mathrm{mph}$ at Central Climatology over the 7-year period 1991-97. Monthly average speeds ranged from $7.0 \mathrm{mph}$ in March to $4.2 \mathrm{mph}$ in November. A winter storm, which developed over the Mid-Atlantic States March 30-31, produced the most notable period of sustained strong winds. Daily and 15minute average wind speeds of 15.3 miles per hour (mph) and $25.1 \mathrm{mph}$, respectively. The maximum instantaneous gust for the year, $58.3 \mathrm{mph}$, occurred during a thunderstorm on April 23. 
Annual and seasonal wind rose plots for wind data collected at the 200-foot level of the Central Climatology tower are shown in figures 13 and 14, respectively. Annual and seasonal wind roses for a five-year data set, 1992-96, are shown in figures 13 and 15, respectively. (The 5-year wind rose data set is comprised primarily of measurements from the H-area tower, approximately 3 miles northeast of Central Climatology).

The annual wind rose for 1997 shows west to northwest winds occurred about 1 percent more often, and northeast winds occurred about 1 percent less often than were observed during the 1992-96 period (Fig. 13). The annual average wind speed at the 200-foot level of the Central Climatology tower was $9.2 \mathrm{mph}$, slightly higher than the average of $9.0 \mathrm{mph}$ over the 7-year period 1991-97.

Wind roses for the $A, C, D$, and $F$ area towers and for the $H, K, L$, and $P$ area towers are shown in figures 16 and 17 , respectively. Wind roses for each of the area towers are similar, except for the D-area tower. Since the D area is located in the Savannah River valley, channeling of the wind by nearby higher terrain to the northeast and southwest resulted in slightly higher frequencies of northwest and southeasterly winds than was observed at the other towers. Annual average wind speeds for the area towers ranged from $7.7 \mathrm{mph}$ at the $\mathrm{D}$ area tower to $9.2 \mathrm{mph}$ at the $\mathrm{C}$ and $\mathrm{P}$ area towers. The frequency statistics used to generate the wind rose plots in figures 13-17 are summarized in Appendix A.

\section{Barometric Pressure}

Average barometric pressure for 1997 was 1005.8 millibars (mb). The lowest daily average value, $985 \mathrm{mb}$, occurred on April 23 as a low pressure system moved over the area. The highest daily average value, $1024.6 \mathrm{mb}$, occurred on February 18 during the passage of a strong Arctic high pressure. Daily average barometric pressure is plotted in Figure 18. The greatest variability in daily average pressure occurred in January through March and again in November through December as mid-latitude low pressure systems and fronts begin to migrate through the area.

\section{Solar Radiation}

The average daily total solar radiation for the year was 374 langleys per day (ly/day). Monthly average daily values ranged from 530 ly/day in July to 185 ly/day in December. A comparison of observed daily solar radiation to a theoretical, clear sky maximum was performed to infer relative cloudiness. The theoretical values were estimated from tables in Budyko (1974). March, April and August were the 'sunniest' months with an observed average daily solar radiation in excess of 70 percent of the theoretical maximum for the month. 
December was the 'cloudiest' month with an observed average daily solar radiation of 56 percent of the theoretical maximum. Daily total solar radiation is plotted in Figure 19. 


\section{REFERENCES}

1. The Encyclopedia of Climatology, J.E. Oliver and R. W. Fairbridge, ed., Von Nostrand Reinhold, New York, NY (1987).

2. Hunter, C. H., A Climatological Description of the Savannah River Site, WSRC-RP89-313, Westinghouse Savannah River Company (1990).

3. Hoel, D.D., Climatology of the Savannah River Plant Site, DP-1679, E. I. duPont deNemous (1984).

4. Weber, A. H., Comparison of Savannah River Site's Meteorological Databases, WSRC-RP-93-269, WSRC (1993).

5. M. J. Parker and R. P. Addis, SRS Meteorological Monitoring Program, WSRCTR-93-0106, WSRC (1994)

6. R. J. Kurzeja, The Savannah River Technology Center Research and Development Climatology Center, WSRC-TR-93-596, WSRC (1993)

7. National Atmospheric and Atmospheric Administration, Daily Weather Maps for 1997, Climate Analysis Center, Washington, DC (1998).

8. Halpert, M. S. and G. D. Bell, Climate Assessment for 1997, Bulletin of the American Meteorological Society, Vol. 79, No. 5 (1998). 
Table 1. Means and Extremes of SRS Meteorological Data for 1997

\begin{tabular}{|c|c|c|c|c|c|c|c|c|c|c|c|c|c|c|c|c|c|c|c|}
\hline \multirow[b]{3}{*}{$\begin{array}{l}\text { 点 } \\
\text { 일 }\end{array}$} & \multicolumn{12}{|c|}{ Temperatures ( $\left.{ }^{\circ} \mathrm{F}\right)$} & \multicolumn{7}{|c|}{ Precipitation (in) } \\
\hline & \multicolumn{4}{|c|}{ Average } & \multicolumn{4}{|c|}{ Extremes } & \multicolumn{4}{|c|}{ Number of Days } & \multirow[b]{2}{*}{ 吾 } & \multirow[b]{2}{*}{ 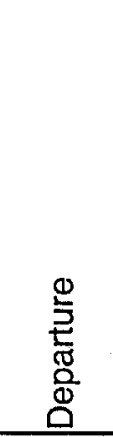 } & \multirow[b]{2}{*}{ 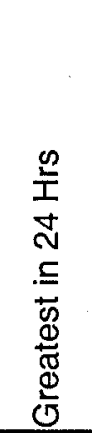 } & \multirow[b]{2}{*}{$\frac{\Phi}{\stackrel{0}{0}}$} & \multicolumn{3}{|c|}{ No. of Days } \\
\hline & 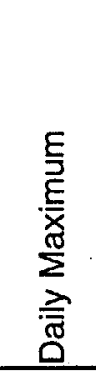 & 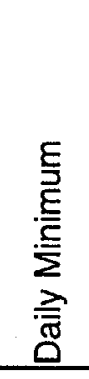 & $\begin{array}{l}\text { F } \\
\stackrel{5}{\mathbf{D}} \\
\end{array}$ & 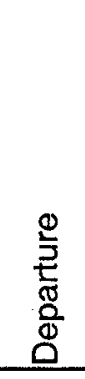 & 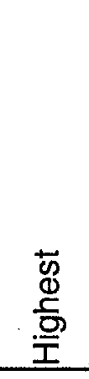 & 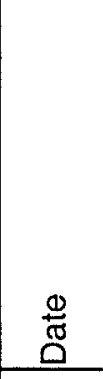 & 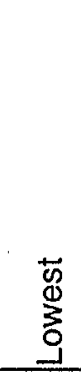 & $\frac{0}{\pi}$ & 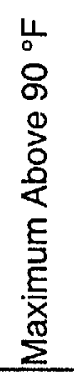 & 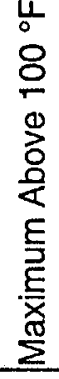 & 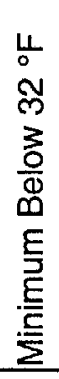 & 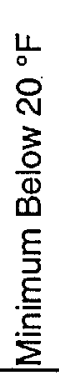 & & & & & 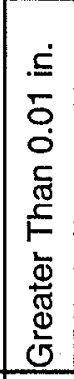 & 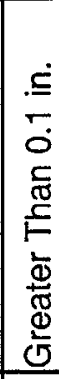 & 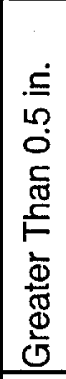 \\
\hline Jan & 57.6 & 38.7 & 48.2 & 2.3 & 74.5 & $1 / 25$ & 18.6 & $1 / 18$ & 0 & 0 & 11 & 1 & 4.73 & 0.25 & 1.14 & $1 / 16$ & 10 & 7 & 5 \\
\hline Feb & 63.1 & 42.8 & 52.9 & 3.6 & 81.7 & $2 / 27$ & 25.2 & $2 / 12$ & 0 & 0 & 3 & 0 & 6.11 & 17 & 1.77 & $2 / 22$ & 8 & 5 & 5 \\
\hline Mar & 75.2 & 52.0 & 63.6 & 6.5 & 83.9 & $3 / 28$ & 32.4 & $3 / 4$ & 0 & 0 & 0 & 0 & 3.04 & -1.70 & 1.44 & $3 / 14$ & 6 & 4 & 2 \\
\hline Apr & 73.1 & 49.2 & 61.2 & -3.4 & 82.3 & $4 / 21$ & 32.7 & $4 / 18$ & 0 & 0 & 0 & 0 & 3 & 0.93 & 2.40 & $4 / 28$ & 9 & 4 & 1 \\
\hline May & 79.5 & 57.4 & 68.5 & -3.6 & 88.3 & $5 / 26$ & 42.8 & $5 / 5$ & 0 & 0 & 0 & 0 & 3.19 & -0.61 & 0.87 & $5 / 3$ & 8 & 5 & 4 \\
\hline Jun & 82.4 & 65.6 & 7 & -4.7 & 91.0 & $6 / 26$ & 5 & 6 & 5 & 0 & 0 & 0 & 7.32 & 2.6 & 2.14 & $6 / 28$ & 12 & 9 & 5 \\
\hline Jul & 90.3 & 70.2 & 80.2 & -1.7 & 97.4 & $7 / 4$ & 61.3 & $7 / 31$ & 19 & 0 & 0 & 0 & 5.94 & 0.42 & 1.51 & $7 / 24$ & 13 & 11 & 4 \\
\hline Aug & 90.5 & 67.6 & 79.0 & -1.4 & 99.1 & $8 / 16$ & 58.7 & $8 / 25$ & 17 & 0 & 0 & 0 & 2.22 & -3.05 & 0.78 & $8 / 18$ & 8 & 5 & 1 \\
\hline Sep & 85.0 & 65.0 & 75.0 & -0.7 & 96.7 & $9 / 20$ & 52.4 & $9 / 6$ & 9 & 0 & 0 & 0 & 5.41 & 1.66 & 2.57 & $9 / 25$ & 8 & 6 & 3 \\
\hline Oct & 73.6 & 54.5 & 64.1 & -1.6 & 86.1 & $10 / 6$ & 38.3 & $10 / 27$ & 0 & 0 & 0 & 0 & 5.49 & 1.96 & 1.93 & $10 / 26$ & 9 & 7 & 3 \\
\hline Nov & 61.7 & 41.5 & 51.6 & -4.6 & 71.7 & $11 / 21$ & 25.7 & $11 / 17$ & 0 & 0 & 4 & 0 & 4.87 & 1.87 & 1.70 & $11 / 13$ & 11 & 7 & 3 \\
\hline Dec & 55.7 & 38.5 & 47.1 & -1.9 & 68.8 & $12 / 1$ & 26.1 & $12 / 8$ & 0 & 0 & 8 & 0 & 10.12 & 6.30 & 2.82 & $12 / 24$ & 10 & 7 & 7 \\
\hline ear & 74.0 & 53.6 & 3.8 & -0.9 & 99.1 & $8 / 16$ & 18.6 & $1 / 18$ & 50 & 0 & 26 & 1 & 62.42 & 12.45 & 2.82 & $12 / 24$ & 112 & 77 & 43 \\
\hline
\end{tabular}


Table 1. Means and Extremes of SRS Meteorological Data for 1997 (cont'd)

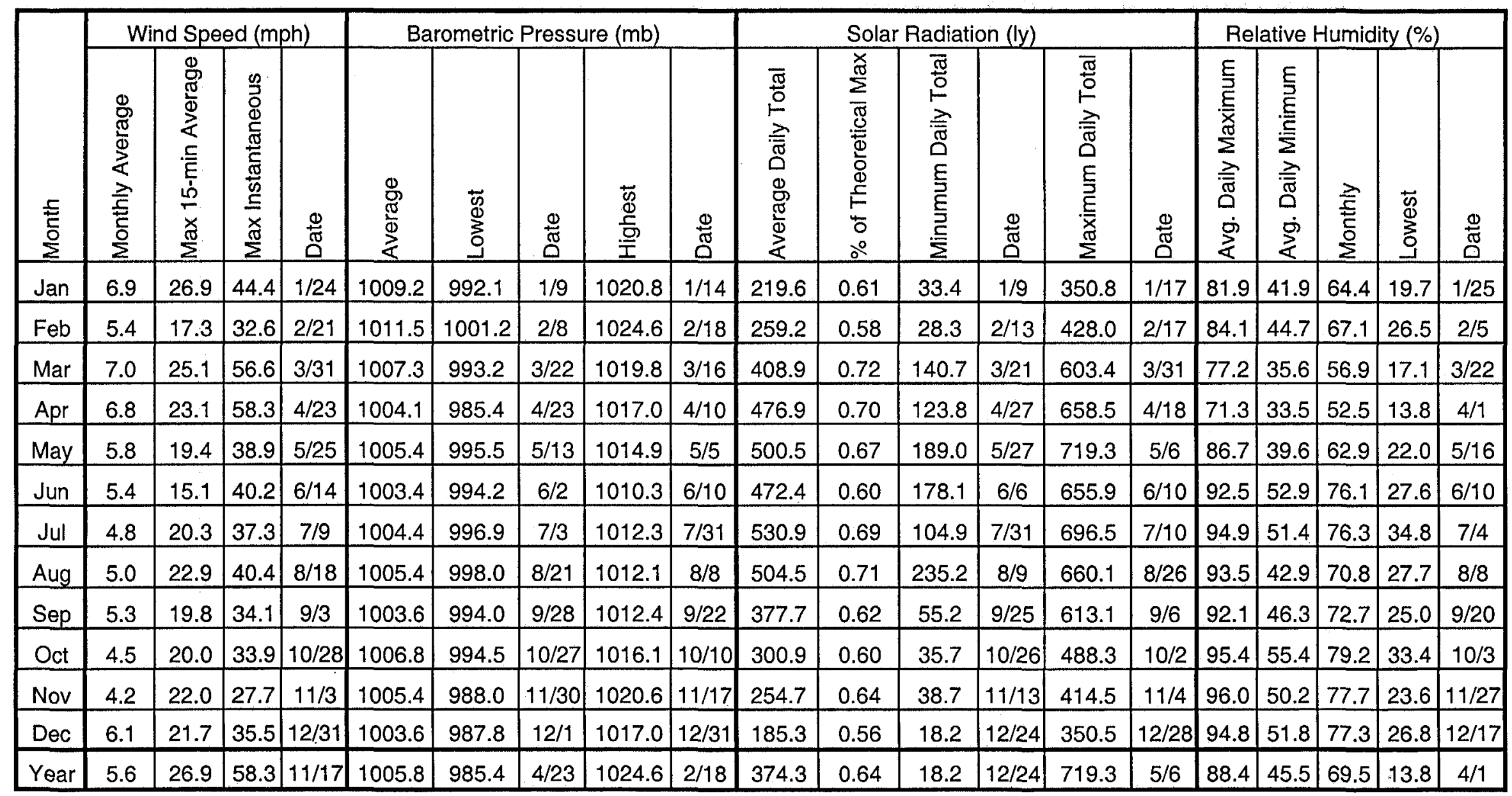


Table 2. Monthly and Annual Average and Extreme Temperatures, 1968-1997

\begin{tabular}{|c|c|c|c|c|c|c|c|c|c|c|c|c|c|}
\hline Year & Jan & Feb & Mar & Apr & May & Jun & Jul & Aug & Sep & Oct & Nov & Dec & Annual \\
\hline 1968 & 43.5 & 43.4 & 57.1 & 66.5 & 71.3 & 80.0 & 83.1 & 82.8 & 77.0 & 67.0 & 55.4 & 45.9 & 64.4 \\
\hline 1969 & 46.5 & 46.6 & 51.5 & 64.5 & 70.5 & 80.3 & 83.3 & 77.6 & 72.8 & 66.1 & 52.1 & 45.4 & 63.1 \\
\hline 1970 & 39.0 & 47.2 & 55.9 & 66.8 & 74.2 & 79.0 & 81.1 & 80.8 & 78.6 & 67.0 & 51.6 & 49.3 & 64.2 \\
\hline 1971 & 44.6 & 46.4 & 49.5 & 63.4 & 70.7 & 81.3 & 80.7 & 80.4 & 75.2 & 70.2 & 55.5 & 56.9 & 64.6 \\
\hline 1972 & 51.7 & 45.6 & 57.6 & 67.4 & 72.4 & 75.3 & 79.7 & 80.6 & 77.2 & 64.8 & 54.4 & 53.2 & 65.0 \\
\hline 1973 & 46.1 & 45.9 & 60.7 & 61.9 & 70.5 & 77.7 & 79.1 & 74.5 & 70.5 & 62.4 & 59.0 & 50.3 & 63.2 \\
\hline 1974 & 59.6 & 50.8 & 62.2 & 66.2 & 75.3 & 77.5 & 81.5 & 80.9 & 75.3 & 64.5 & 56.6 & 49.0 & 66.6 \\
\hline 1975 & 51.4 & 53.2 & 55.8 & 63.9 & 75.6 & 79.1 & 79.7 & 82.4 & 75.7 & 68.7 & 59.3 & 48.5 & 66.1 \\
\hline 1976 & 44.2 & 55.7 & 61.5 & 64.8 & 68.9 & 75.6 & 80.4 & 78.0 & 73.1 & 60.1 & 48.7 & 44.8 & 63.0 \\
\hline 1977 & 35.3 & 47.1 & 60.0 & 66.9 & 73.3 & 80.6 & 83.6 & 80.6 & 77.9 & 62.1 & 58.2 & 46.7 & 64.4 \\
\hline 1978 & 39.3 & 41.3 & 54.2 & 65.7 & 70.9 & 79.7 & 82.1 & 81.2 & 77.1 & 65.6 & 60.7 & 49.6 & 64.0 \\
\hline 1979 & 42.1 & 44.6 & 57.5 & 64.5 & 71.3 & 75.1 & 79.6 & 80.5 & 73.4 & 64.8 & 57.4 & 47.4 & 63.2 \\
\hline 1980 & 45.9 & 44.3 & 52.6 & 63.5 & 71.2 & 78.3 & 83.8 & 82.5 & 79.2 & 62.7 & 52.8 & 46.0 & 63.6 \\
\hline 1981 & 40.4 & 48.5 & 53.0 & 67.0 & 68.6 & 81.3 & 81.3 & 76.3 & 74.0 & 62.1 & 54.4 & 43.2 & 62.5 \\
\hline 1982 & 43.0 & 50.0 & 58.9 & 62.4 & 75.7 & 78.8 & 80.9 & 80.1 & 75.0 & 66.2 & 58.7 & 54.8 & 65.4 \\
\hline 1983 & 43.3 & 48.0 & 55.3 & 59.4 & 66.8 & 76.7 & 84.3 & 83.9 & 74.8 & 67.2 & 56.4 & 45.8 & 63.5 \\
\hline 1984 & 45.0 & 51.7 & 56.5 & 62.6 & 71.9 & 80.1 & 80.1 & 80.8 & 74.0 & 73.4 & 53.4 & 56.9 & 65.5 \\
\hline 1985 & 42.9 & 49.5 & 60.2 & 67.5 & 74.5 & 80.8 & 81.1 & 79.7 & 75.7 & 70.8 & 65.5 & 45.4 & 66.1 \\
\hline 1986 & 45.4 & 54.6 & 57.9 & 66.4 & 74.4 & 82.7 & 86.9 & 80.1 & 78.4 & 67.1 & 61.3 & 49.3 & 67.0 \\
\hline 1987 & 46.2 & 48.6 & 56.5 & 62.3 & 74.5 & 79.9 & 82.8 & 83.8 & 76.6 & 60.7 & 59.1 & 52.9 & 65.3 \\
\hline 1988 & 42.3 & 47.8 & 56.8 & 64.2 & 70.4 & 76.8 & 81.6 & 81.4 & 75.4 & 61.2 & 58.0 & 49.1 & 63.8 \\
\hline 1989 & 52.2 & 52.0 & 58.3 & 64.2 & 70.6 & 79.8 & 81.4 & 80.9 & 75.3 & 67.3 & 52.4 & 44.2 & 64.9 \\
\hline 1990 & 54.9 & 57.5 & 60.0 & 64.0 & 72.9 & 80.5 & 83.7 & 83.8 & 79.0 & 69.4 & 59.9 & 54.6 & 68.4 \\
\hline 1991 & 47.9 & 54.1 & 60.3 & 69.2 & 76.9 & 79.5 & 83.6 & 81.2 & 77.4 & 68.1 & 55.4 & 54.0 & 67.3 \\
\hline 1992 & 49.5 & 54.1 & 57.2 & 65.0 & 71.2 & 78.9 & 83.7 & 80.7 & 76.9 & 65.0 & 57.1 & 48.0 & 65.6 \\
\hline 1993 & 51.7 & 47.8 & 53.2 & 58.9 & 69.7 & 78.2 & 83.6 & 80.0 & 75.2 & 62.8 & 55.2 & 43.6 & 63.3 \\
\hline 1994 & 41.5 & 50.1 & 60.2 & 68.0 & 71.2 & 82.3 & 81.8 & 81.2 & 77.4 & 67.2 & 62.3 & 53.3 & 66.4 \\
\hline 1995 & 45.5 & 49.9 & 58.6 & 65.9 & 73.5 & 75.0 & 79.9 & 79.0 & 71.8 & 65.9 & 50.8 & 43.8 & 63.3 \\
\hline 1996 & 44.6 & 50.1 & 50.6 & 61.6 & 72.9 & 76.5 & 79.3 & 76.0 & 72.7 & 62.1 & 51.6 & 48.8 & 62.2 \\
\hline 1997 & 48.2 & 52.9 & 63.3 & 61.2 & 68.5 & 74.0 & 80.2 & 79.0 & 75.0 & 64.1 & 51.6 & 47.0 & 63.7 \\
\hline
\end{tabular}

\begin{tabular}{|c|c|c|c|c|c|c|c|c|c|c|c|c|c|}
\hline Avg & 45.8 & 49.3 & 57.1 & 64.5 & 72.0 & 78.7 & 81.8 & 80.4 & 75.6 & 65.6 & 56.2 & 48.9 & 64.7 \\
\hline Lowest Mon & 35.3 & 41.3 & 49.5 & 58.9 & 66.8 & 74.0 & 79.1 & 74.5 & 70.5 & 60.1 & 48.7 & 43.2 & 62.2 \\
\hline Yr Lowest & 1977 & 1978 & 1971 & 1993 & 1983 & 1997 & 1967 & 1973 & 1973 & 1976 & 1976 & 1981 & 1996 \\
\hline Rec Low & -3 & 10 & 11 & 29 & 38 & 48 & 56 & 56 & 41 & 28 & 18 & 5 & -3 \\
\hline Yr Rec & 1985 & 1996 & 1980 & 1983 & 1989 & 1984 & 1963 & 1986 & 1967 & 1976 & 1970 & 1962 & 1985 \\
\hline Highest Mon & 59.6 & 57.5 & 63.3 & 69.2 & 76.9 & 82.7 & 86.9 & 83.9 & 79.2 & 73.4 & 65.5 & 56.9 & 68.4 \\
\hline Yr Highest & 1974 & 1990 & 1997 & 1991 & 1991 & 1986 & 1986 & 1983 & 1980 & 1984 & 1985 & 1971 & 1990 \\
\hline Rec High & 86 & 86 & 90 & 99 & 102 & 105 & 107 & 107 & 104 & 96 & 89 & 82 & 107 \\
\hline Yr Rec & 1975 & 1989 & 1974 & 1986 & 1963 & 1985 & 1986 & 1983 & 1990 & 1986 & 19874 & 1984 & 1986 \\
\hline
\end{tabular}


Table 3. Monthly and Annual Rainfall, 1968-1997

\begin{tabular}{|c|c|c|c|c|c|c|c|c|c|c|c|c|c|}
\hline Year & Jan & Feb & Mar & Apr & May & Jun & Jul & Aug & Sep & Oct & Nov & Dec & Annual \\
\hline 1968 & 3.98 & 0.94 & 1.49 & 2.12 & 3.46 & 6.20 & 3.88 & 4.27 & 2.24 & 3.00 & 3.39 & 2.73 & 37.70 \\
\hline 1969 & 2.00 & 2.46 & 3.38 & 4.09 & 3.02 & 3.95 & 2.71 & 5.42 & 4.56 & 1.16 & 0.40 & 4.19 & 37.34 \\
\hline 1970 & 2.79 & 2.69 & 7.36 & 1.38 & 4.16 & 3.46 & 4.85 & 3.79 & 1.71 & 5.01 & 1.68 & 4.92 & 43.80 \\
\hline 1971 & 5.11 & 4.16 & 8.68 & 2.92 & 2.98 & 5.92 & 10.53 & 8.76 & 3.80 & 5.95 & 2.31 & 2.89 & 64.01 \\
\hline 1972 & 8.91 & 4.42 & 2.82 & 0.57 & 4.72 & 6.57 & 2.64 & 6.05 & 1.47 & 1.20 & 3.56 & 5.23 & 48.16 \\
\hline 1973 & 5.36 & 5.26 & 6.38 & 4.58 & 3.50 & 10.89 & 6.04 & 3.81 & 3.71 & 1.22 & 0.31 & 4.64 & 55.70 \\
\hline 1974 & 2.58 & 7.03 & 2.87 & 2.93 & 4.15 & 2.79 & 4.08 & 6.27 & 3.22 & 0.08 & 2.19 & 3.83 & 42.02 \\
\hline 1975 & 4.98 & 6.64 & 5.91 & 4.42 & 5.15 & 3.84 & 8.55 & 3.83 & 5.18 & 1.74 & 3.41 & 2.03 & 55.68 \\
\hline 1976 & 4.18 & 1.08 & 3.83 & 2.50 & 10.90 & 4.35 & 1.95 & 1.64 & 5.48 & 4.92 & 4.19 & 5.08 & 50.10 \\
\hline 1977 & 3.72 & 1.63 & 6.86 & 1.27 & 1.76 & 2.47 & 3.42 & 7.30 & 5.50 & 4.27 & 1.63 & 3.86 & 43.69 \\
\hline 1978 & 10.02 & 1.32 & 3.07 & 3.53 & 3.64 & 3.43 & 4.14 & 5.11 & 4.06 & 0.06 & 3.54 & 1.88 & 43.80 \\
\hline 1979 & 3.59 & 7.74 & 3.09 & 6.49 & 8.94 & 1.54 & 7.85 & 2.12 & 6.13 & 1.35 & 3.95 & 2.17 & 54.96 \\
\hline 1980 & 5.12 & 3.48 & 10.96 & 1.69 & 3.49 & 2.99 & 0.90 & 2.03 & 5.86 & 2.14 & 2.50 & 1.91 & 43.07 \\
\hline 1981 & 0.89 & 5.02 & 4.72 & 2.07 & 6.90 & 4.29 & 3.97 & 5.79 & 0.54 & 2.81 & 1.00 & 9.55 & 47.55 \\
\hline 1982 & 3.94 & 4.45 & 2.50 & 5.68 & 2.72 & 4.27 & 11.48 & 5.00 & 4.62 & 3.87 & 2.40 & 4.83 & 55.76 \\
\hline 1983 & 3.77 & 7.21 & 6.77 & 5.77 & 1.67 & 6.57 & 4.85 & 6.32 & 3.46 & 1.92 & 5.38 & 4.15 & 57.84 \\
\hline 1984 & 3.51 & 7.09 & 6.05 & 8.00 & 9.79 & 2.54 & 7.28 & 5.52 & 0.60 & 0.31 & 0.90 & 1.38 & 52.97 \\
\hline 1985 & 3.01 & 6.91 & 1.31 & 0.84 & 1.70 & 4.61 & 8.10 & 4.37 & 0.49 & 6.34 & 6.36 & 2.48 & 46.52 \\
\hline 1986 & 1.46 & 3.56 & 4.08 & 1.44 & 3.83 & 3.00 & 2.96 & 10.89 & 1.54 & 4.18 & 5.82 & 5.82 & 48.58 \\
\hline 1987 & 7.39 & 7.55 & 4.97 & 0.69 & 3.57 & 5.64 & 4.86 & 4.92 & 3.55 & 0.29 & 2.74 & 1.41 & 47.58 \\
\hline 1988 & 4.15 & 3.18 & 2.90 & 4.75 & 2.85 & 7.11 & 1.78 & 6.77 & 4.40 & 3.39 & 2.16 & 2.91 & 46.35 \\
\hline 1989 & 1.42 & 3.59 & 5.52 & 4.89 & 2.60 & 6.67 & 11.46 & 3.27 & 4.87 & 3.35 & 2.99 & 4.41 & 55.04 \\
\hline 1990 & 3.07 & 2.38 & 2.37 & 1.21 & 2.95 & 0.89 & 7.31 & 8.07 & 0.62 & 19.62 & 3.11 & 1.57 & 53.17 \\
\hline 1991 & 7.03 & 1.84 & 5.44 & 4.73 & 3.06 & 2.17 & 7.89 & 9.26 & 4.40 & 0.99 & 1.55 & 3.32 & 51.68 \\
\hline 1992 & 4.45 & 3.89 & 2.98 & 2.40 & 1.34 & 6.27 & 3.69 & 4.84 & 6.38 & 3.11 & 7.78 & 2.86 & 49.99 \\
\hline 1993 & 7.50 & 3.62 & 8.37 & 1.75 & 1.43 & 3.27 & 3.12 & 2.48 & 7.29 & 4.13 & 1.87 & 1.81 & 46.64 \\
\hline 1994 & 4.80 & 3.91 & 6.42 & 1.04 & 1.45 & 5.08 & 7.47 & 3.47 & 1.67 & 10.01 & 3.05 & 4.62 & 52.99 \\
\hline 1995 & 6.95 & 7.97 & 0.91 & 1.28 & 1.77 & 8.15 & 5.71 & 6.92 & 5.75 & 2.64 & 2.38 & 4.47 & 54.90 \\
\hline 1996 & 3.97 & 2.71 & 7.27 & 2.62 & 3.31 & 3.36 & 6.24 & 7.70 & 4.03 & 2.35 & 1.65 & 3.49 & 48.70 \\
\hline 1997 & 4.73 & 6.11 & 3.04 & 3.98 & 3.19 & 7.67 & 5.94 & 2.22 & 5.41 & 4.6 & 5.69 & 10.19 & 62.77 \\
\hline
\end{tabular}

\begin{tabular}{|c|c|c|c|c|c|c|c|c|c|c|c|c|c|}
\hline Avg & 4.48 & 4.33 & 4.74 & 3.05 & 3.80 & 4.67 & 5.52 & 5.27 & 3.75 & 3.53 & 3.00 & 3.82 & 49.97 \\
\hline Min & 0.89 & 0.94 & 0.91 & 0.57 & 1.31 & 0.89 & 0.90 & 1.04 & 0.49 & 0.06 & 0.21 & 0.46 & 28.82 \\
\hline Yr Min & 1981 & 1968 & 1995 & 1972 & 1965 & 1990 & 1980 & 1963 & 1985 & 1963 & 1958 & 1955 & 1954 \\
\hline $\operatorname{Max}$ & 10.02 & 7.97 & 10.96 & 8.20 & 10.90 & 10.89 & 11.48 & 12.34 & 8.71 & 19.62 & 7.78 & 10.19 & 73.47 \\
\hline Yr Max & 1978 & 1995 & 1980 & 1961 & 1976 & 1973 & 1982 & 1964 & 1959 & 1990 & 1992 & 1997 & 1964 \\
\hline
\end{tabular}


Figure 1. Summary of Daily Data for 1997
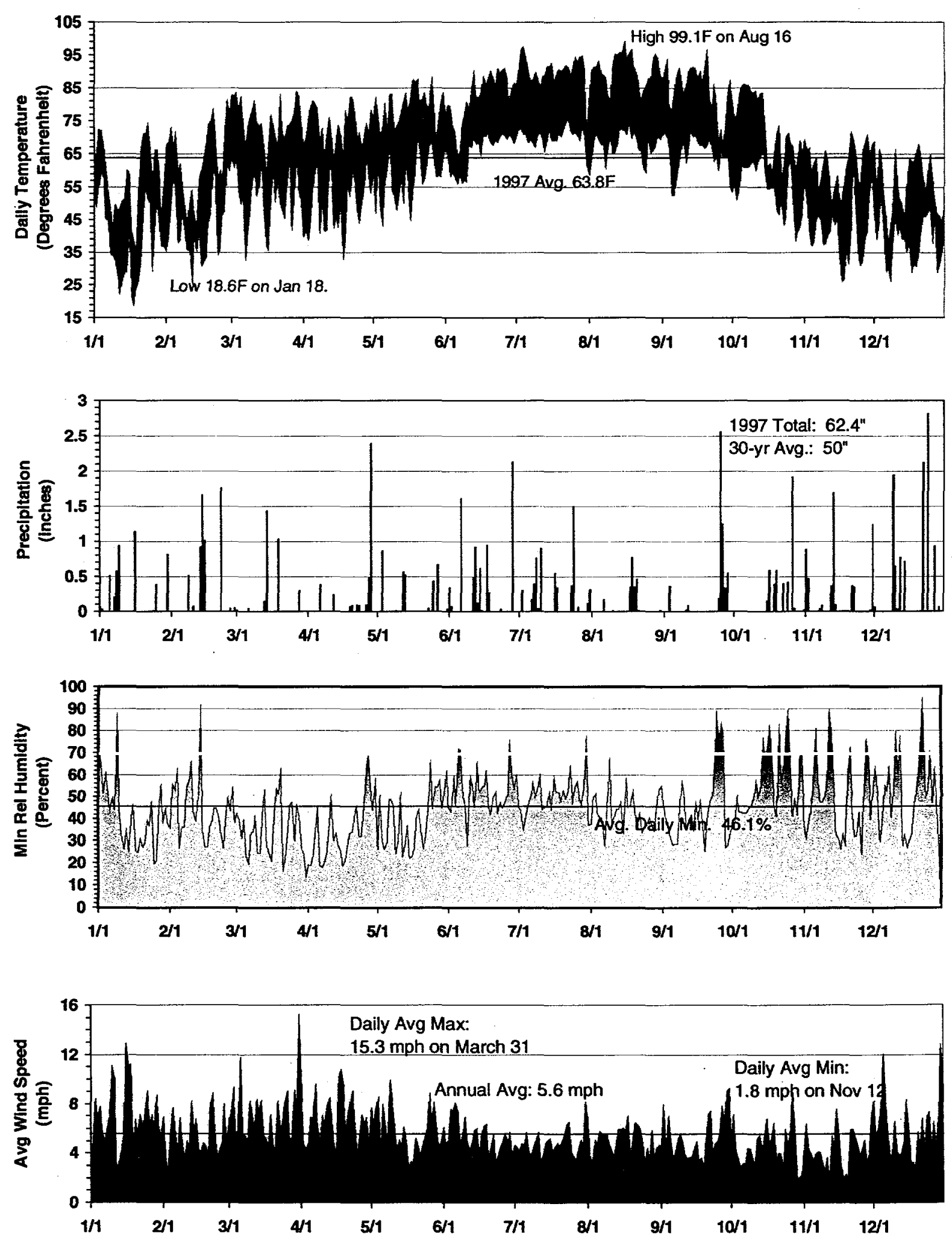


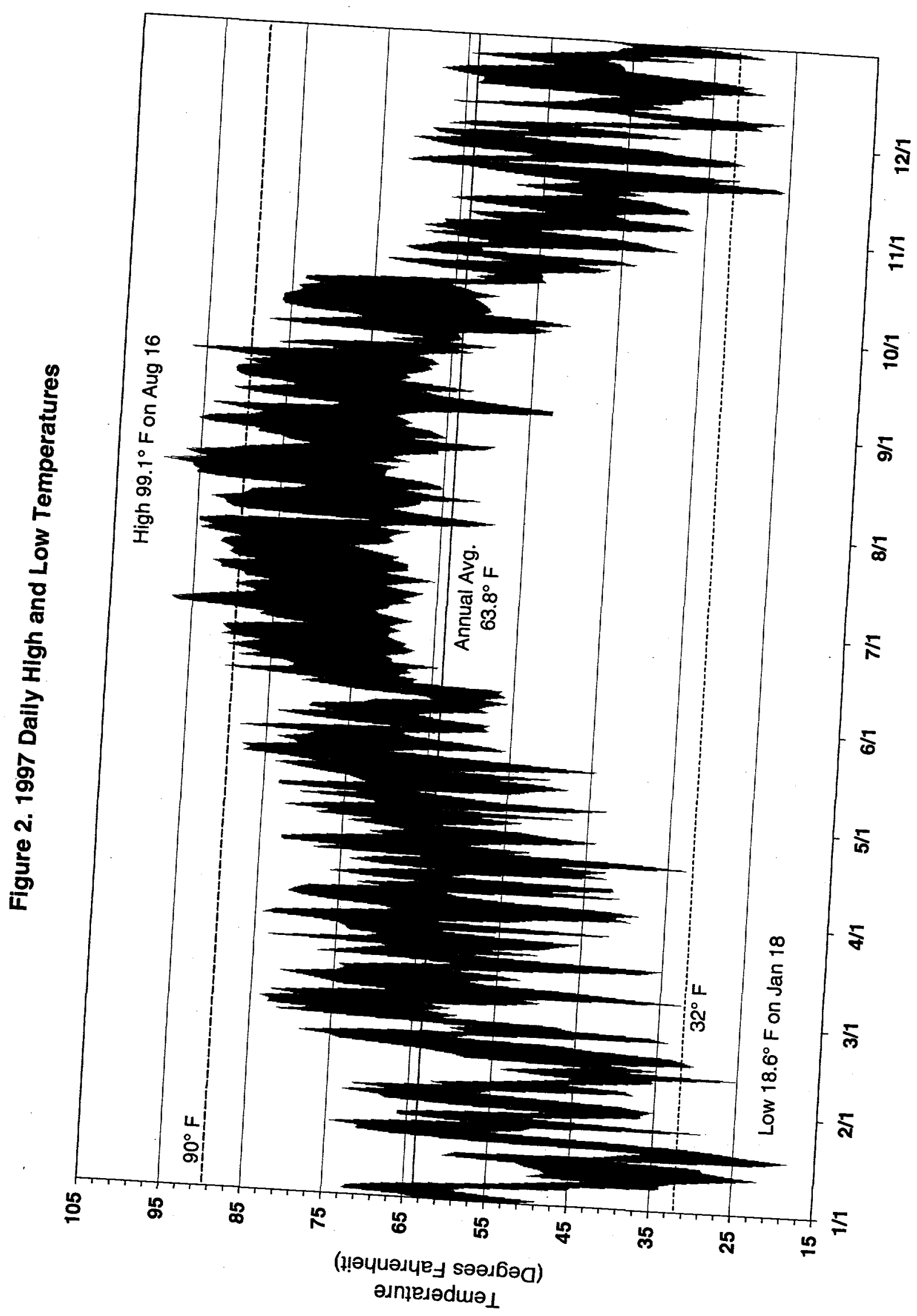


Figure 3. SRS Annual Average Temperature 1968-1997

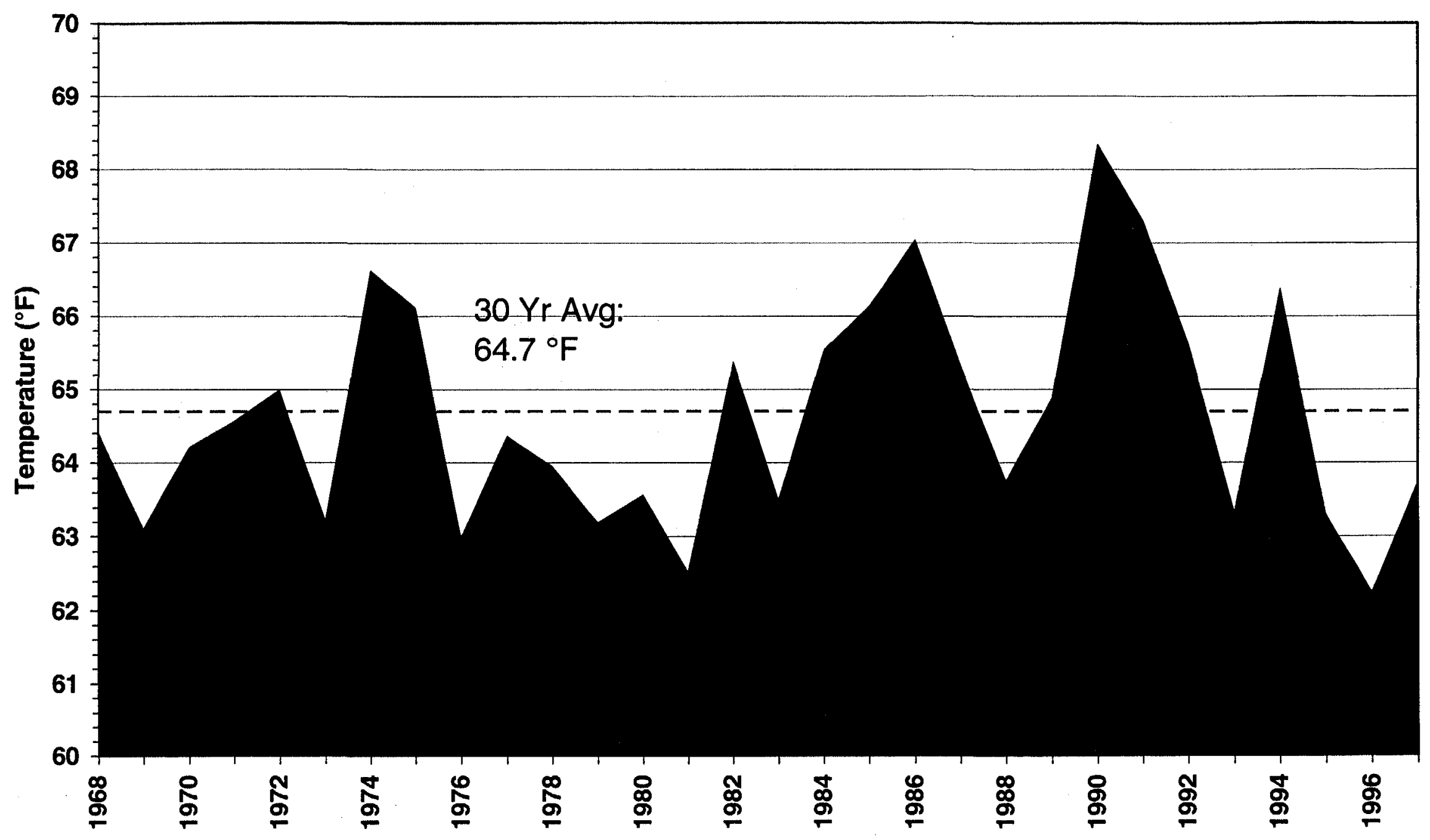


Figure 4. SRS Monthly Average Temperature

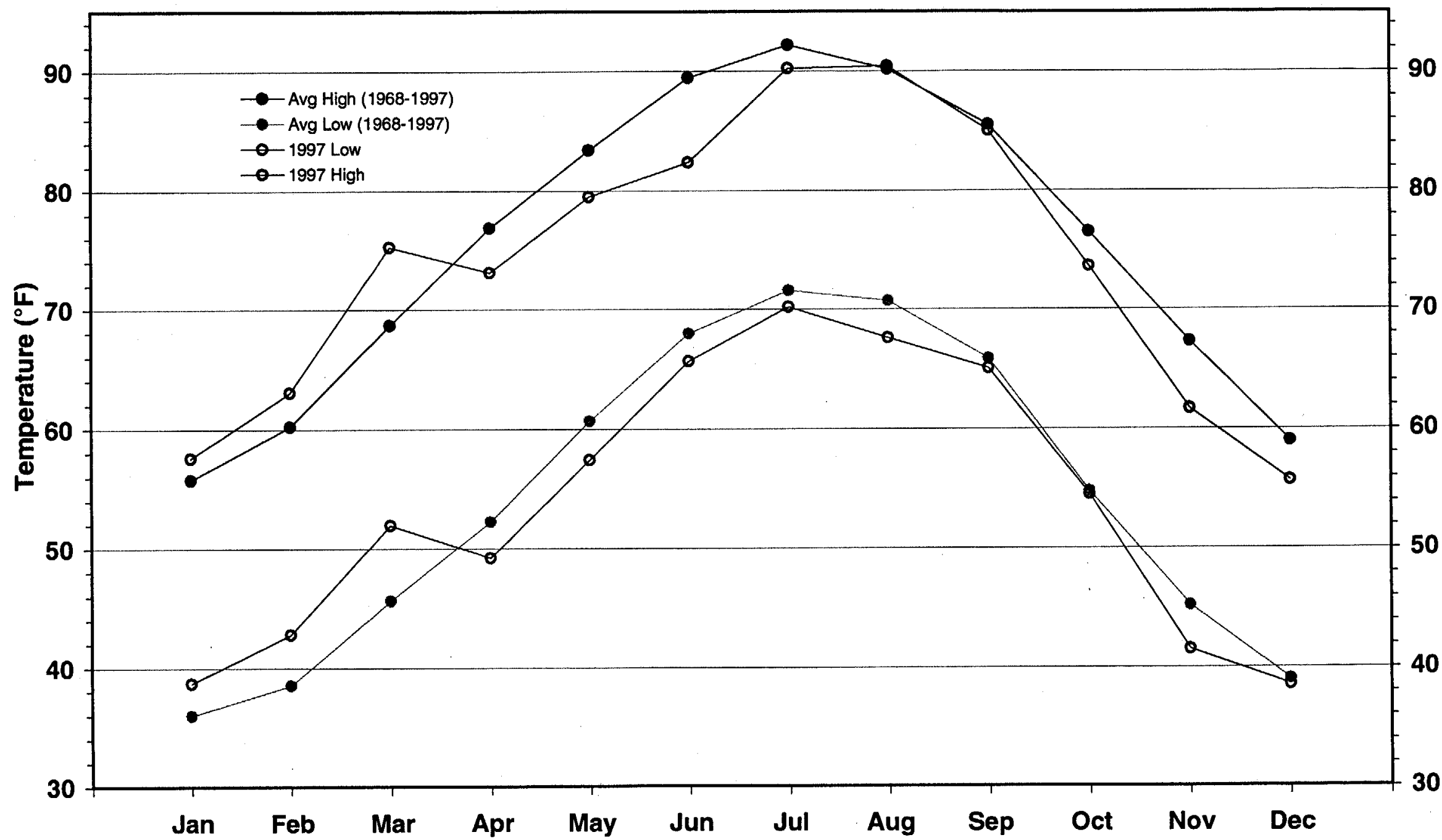


Figure 5. Number of Freezing ( $<32 \mathrm{~F}$ ) and Sweltering ( $>90 \mathrm{~F}$ ) Days

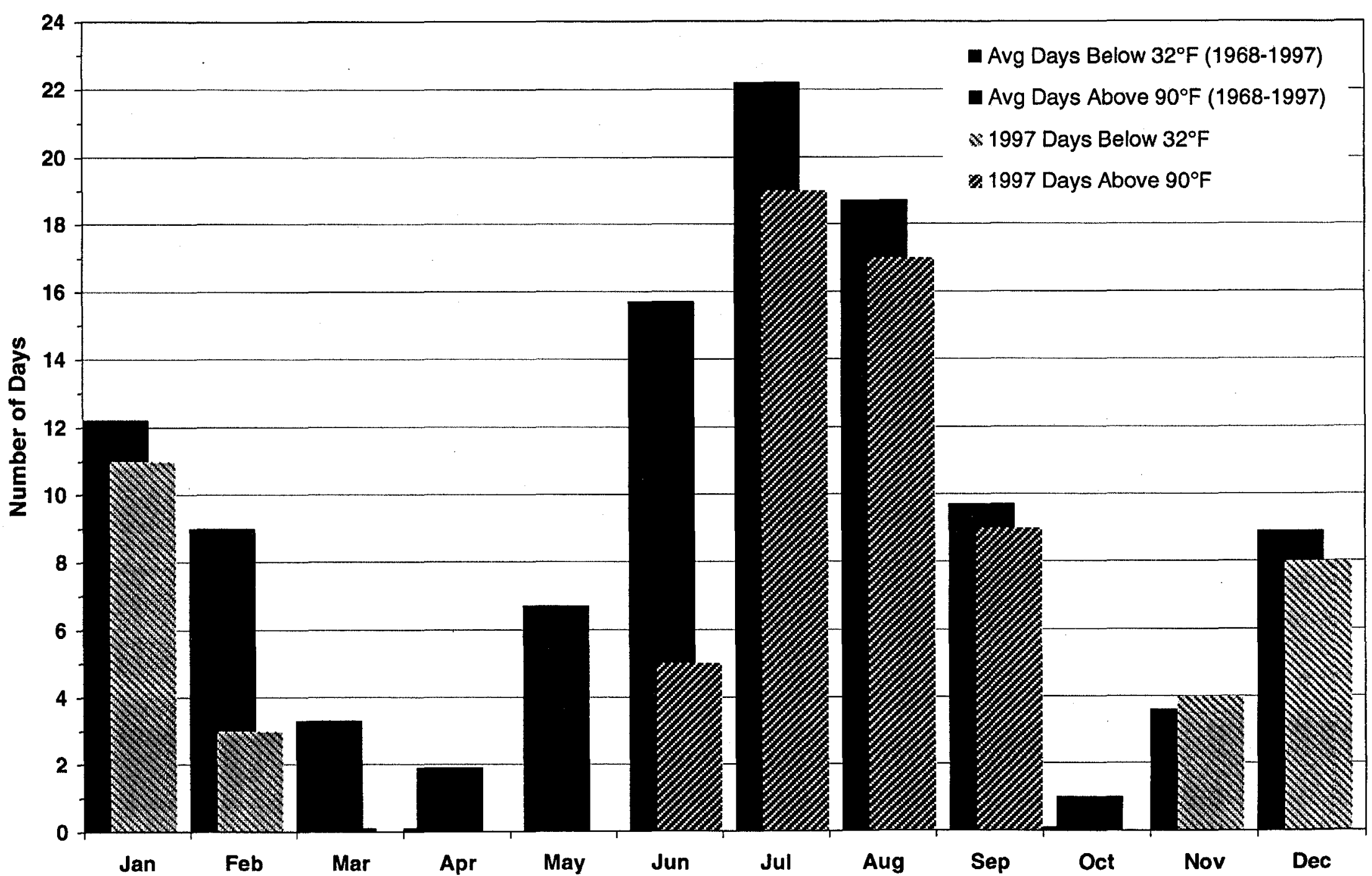




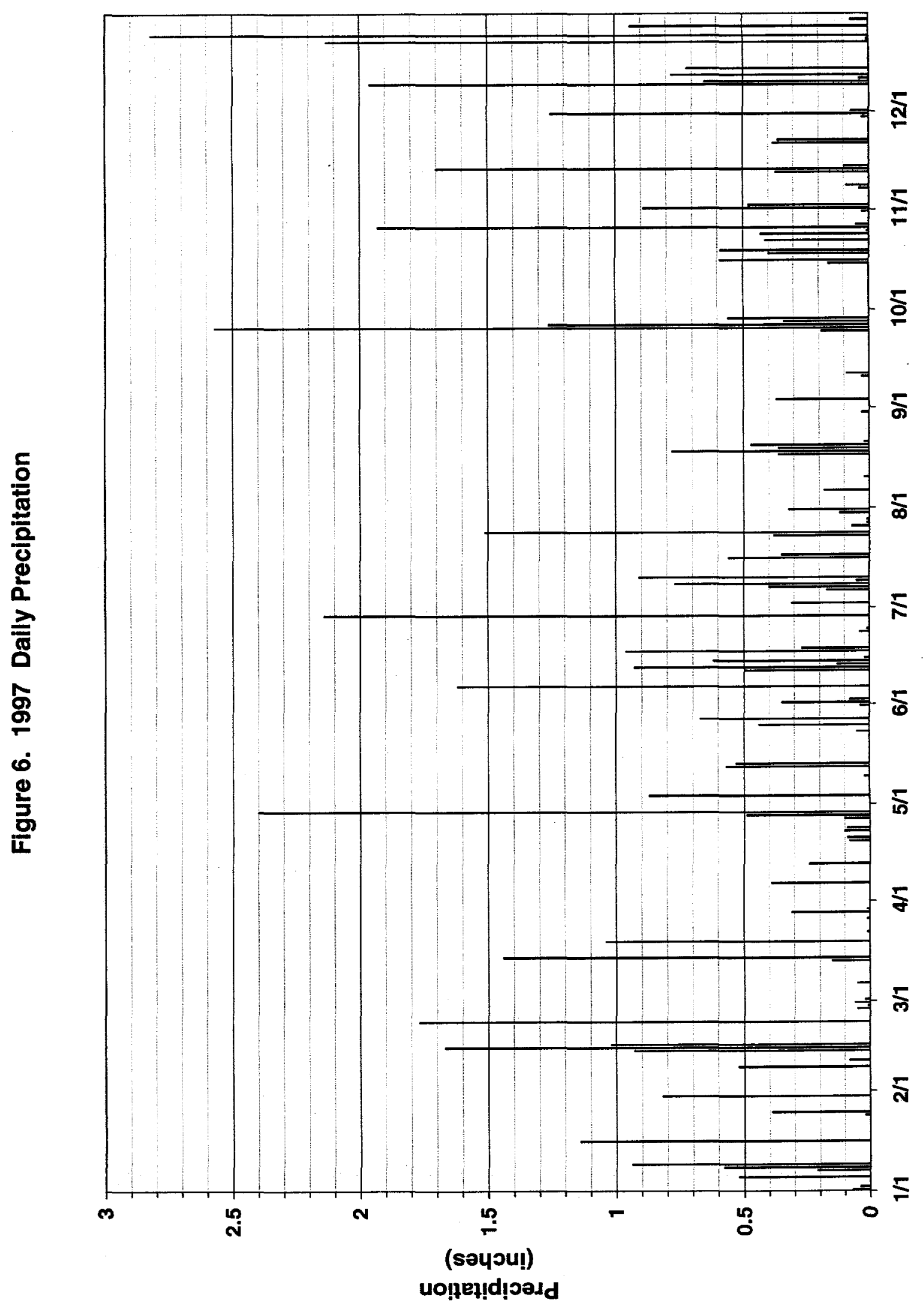




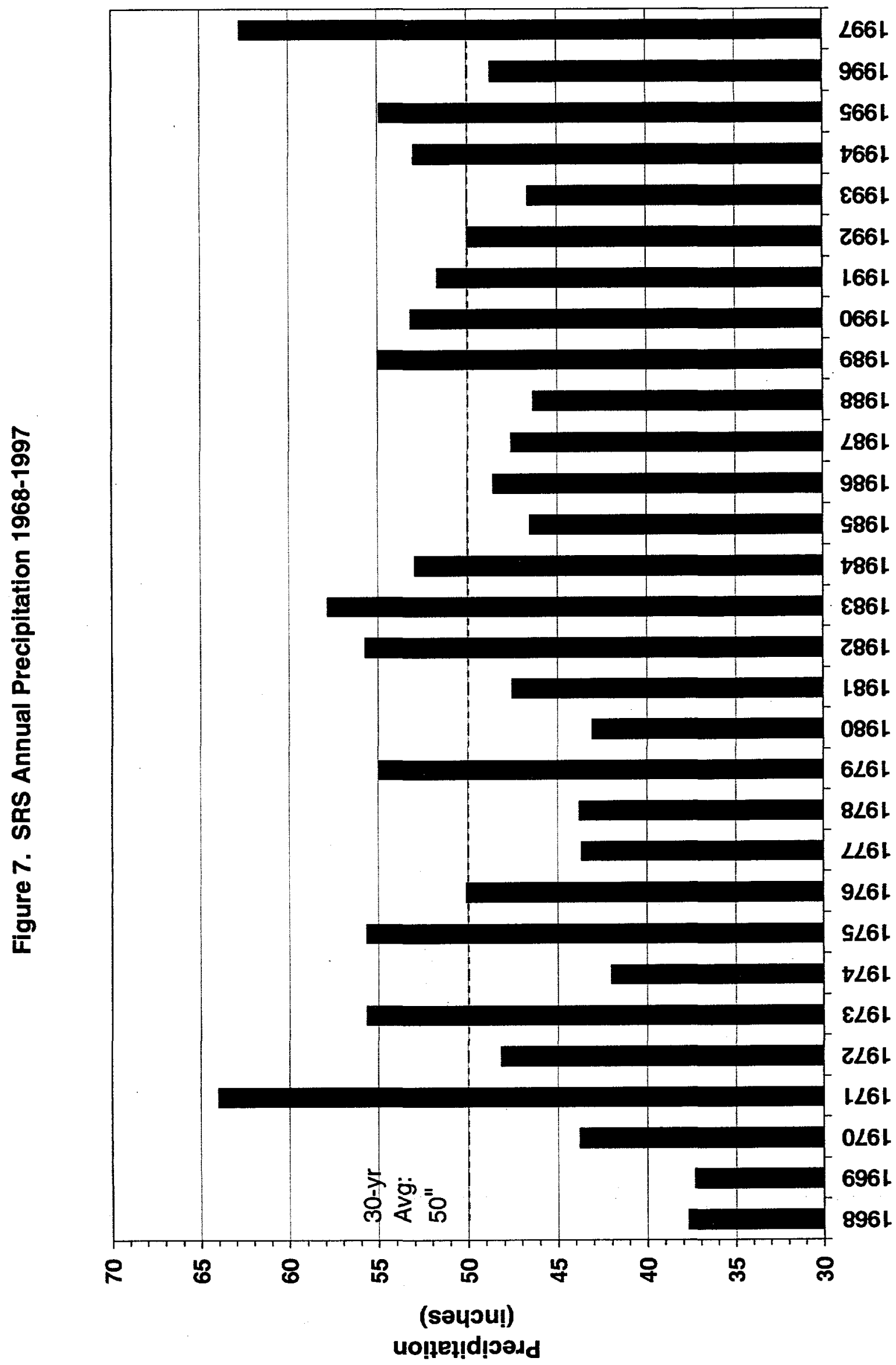




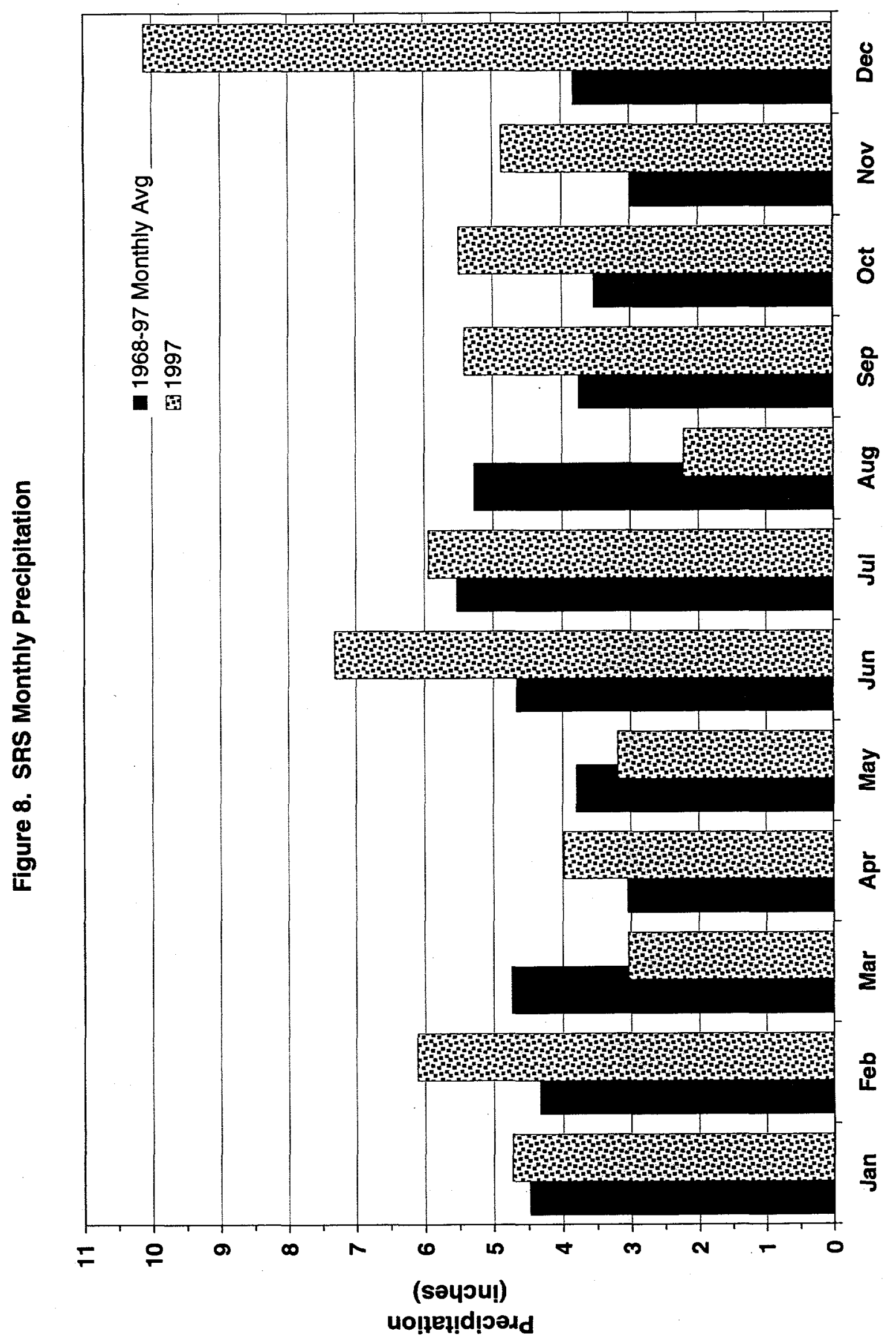




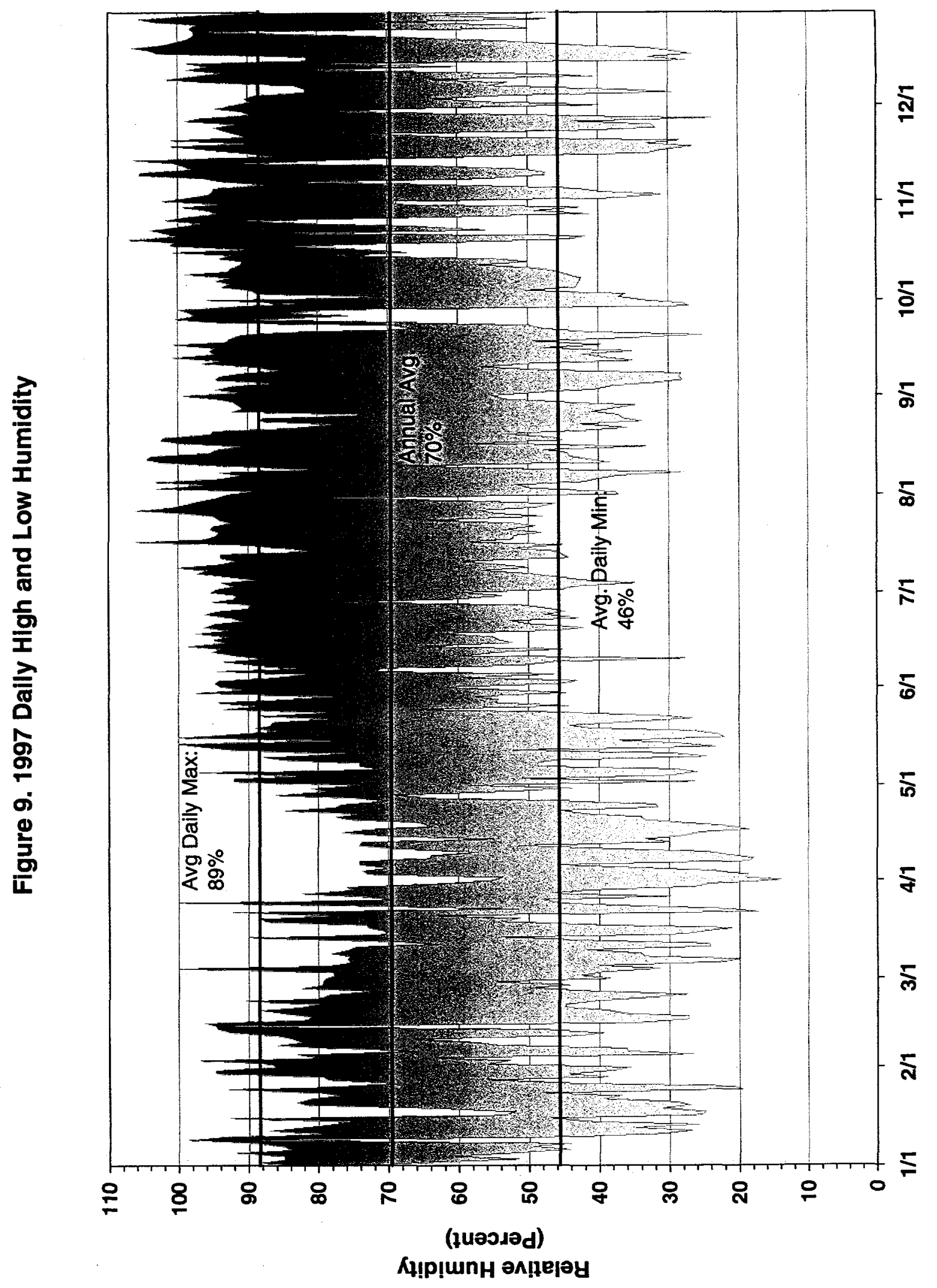




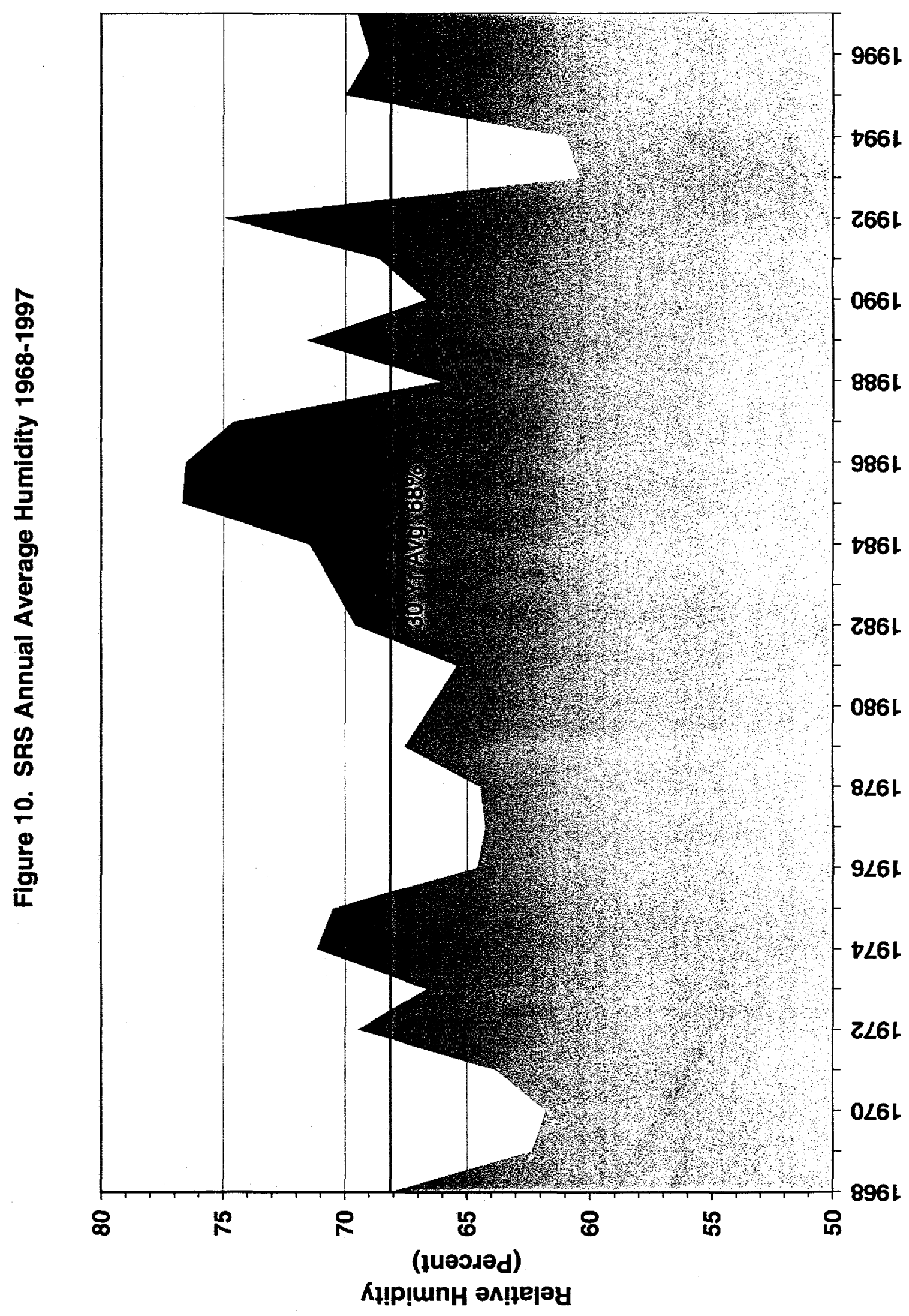


Figure 11. SRS Monthly Average Minimum Humidity

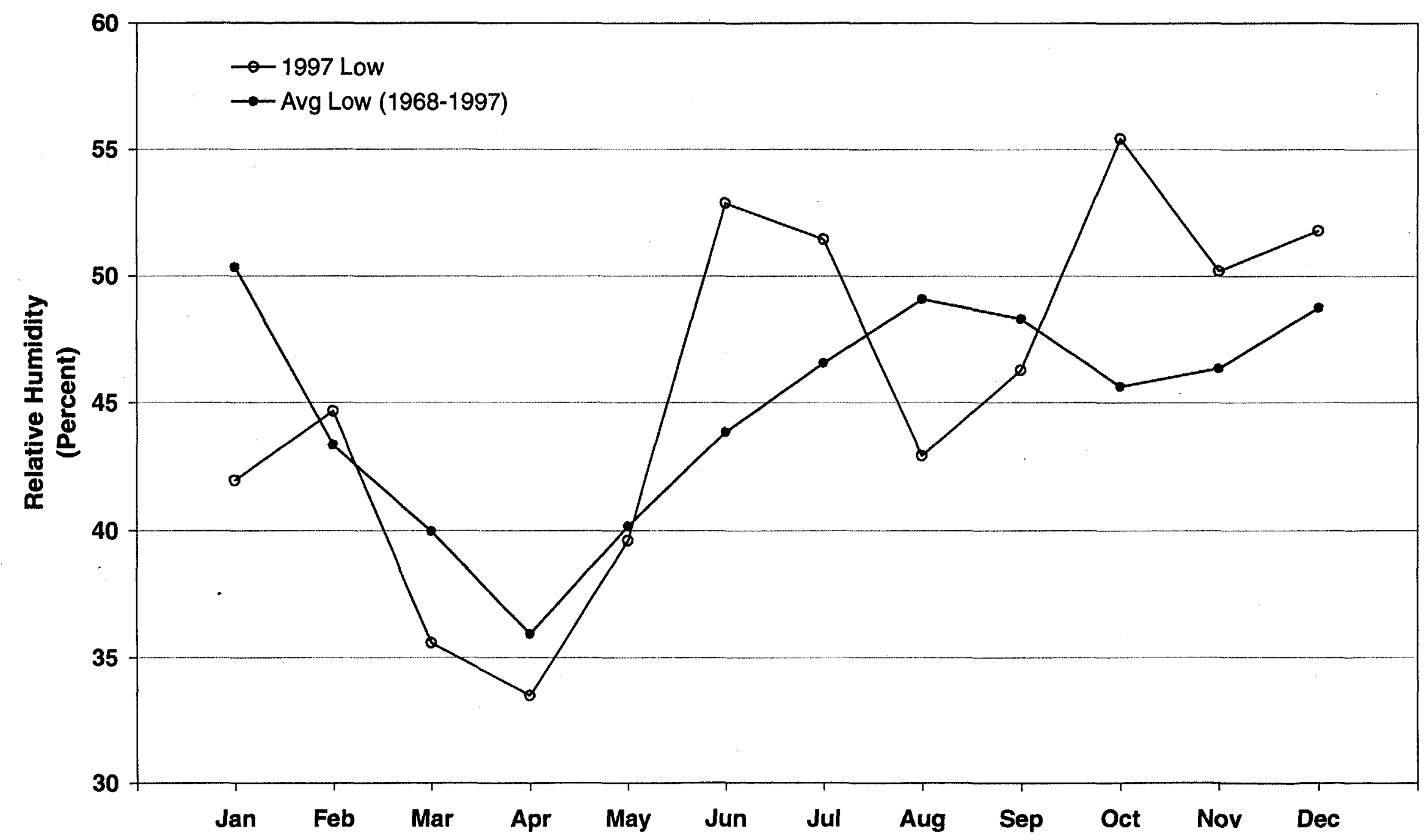


Figure 12. 1997 Daily Average Wind Speed

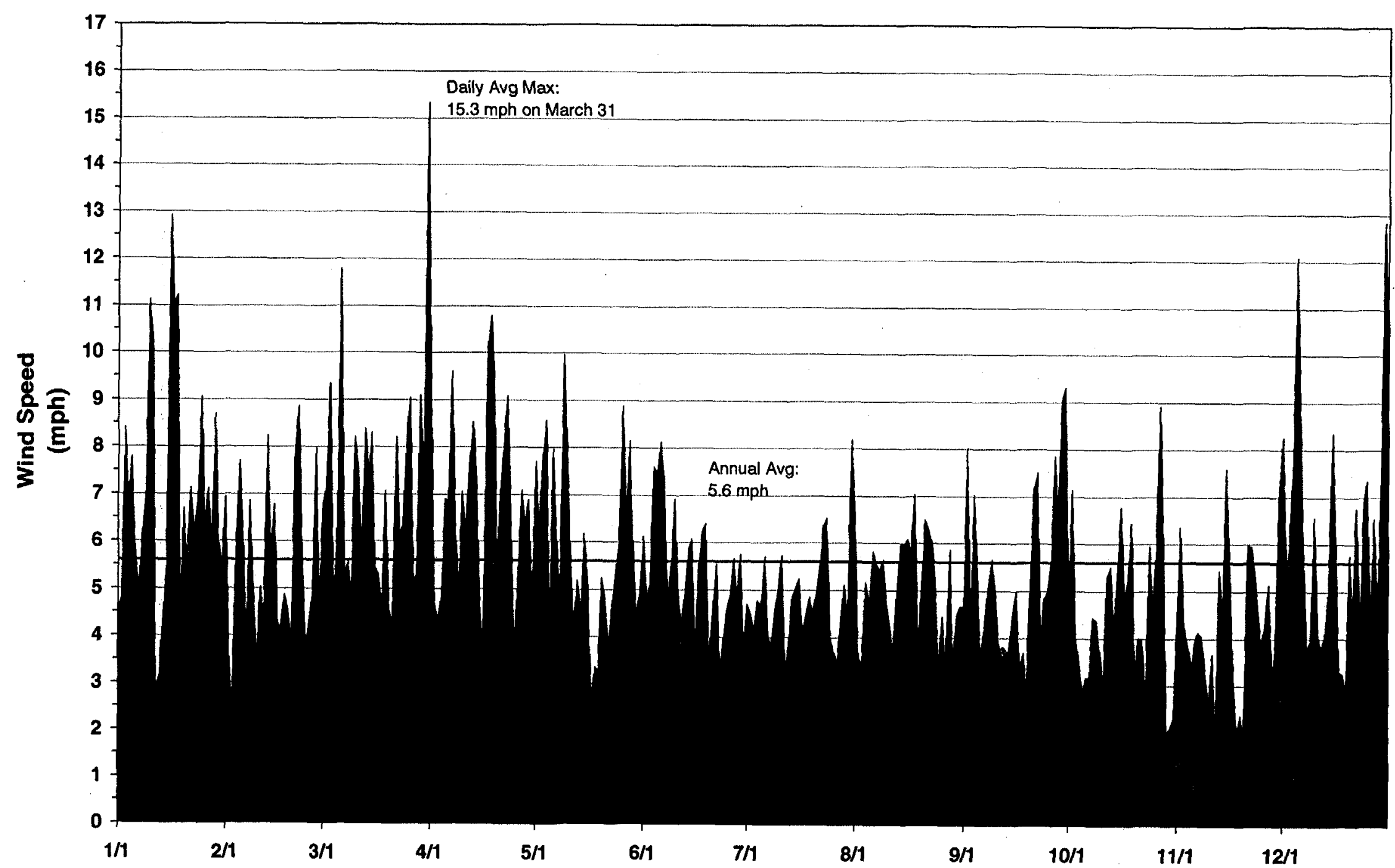




\section{FIGURE 13. Annual Wind Rose Plots}

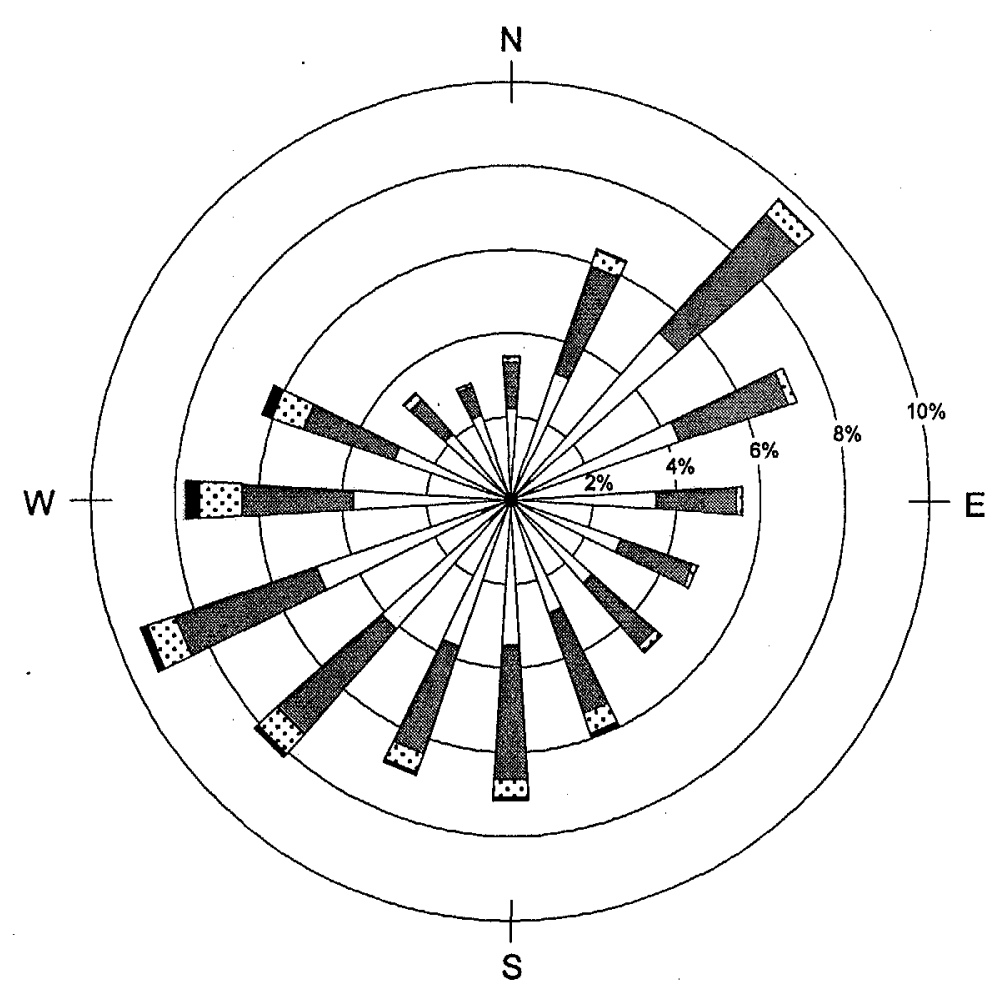

$1992-96$

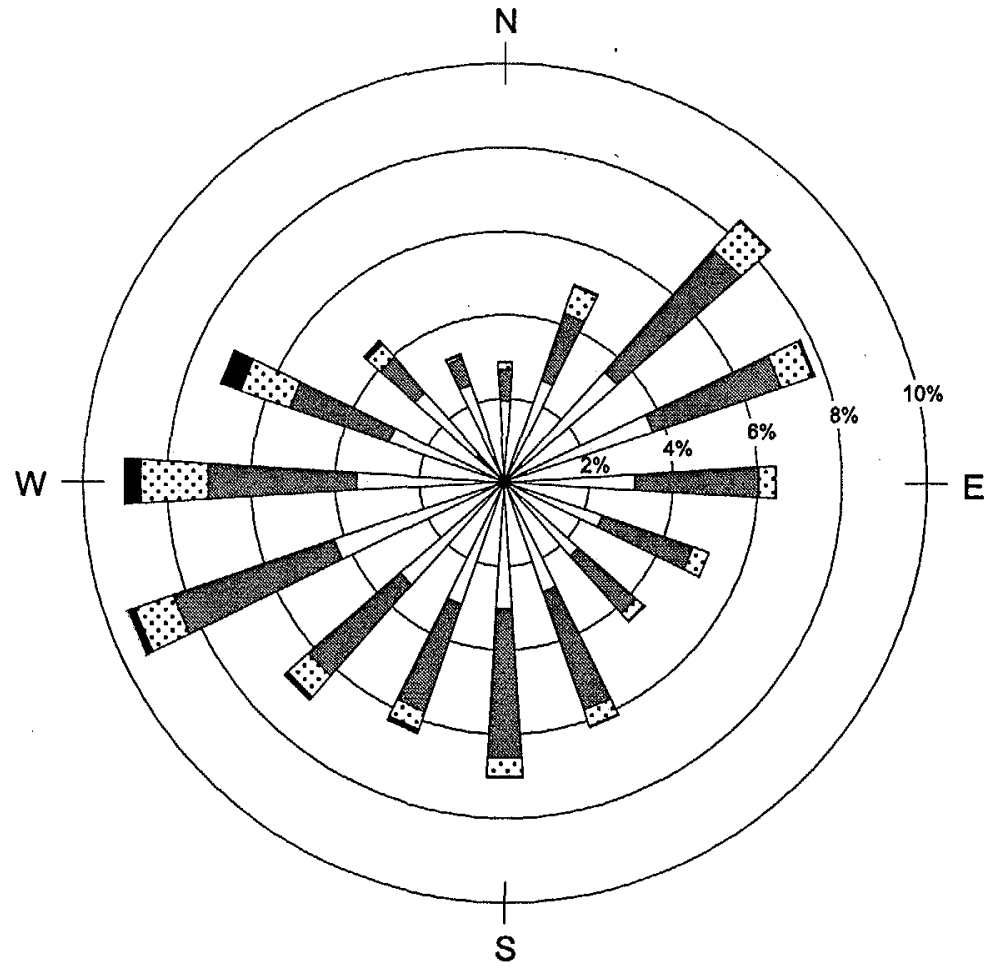

1997

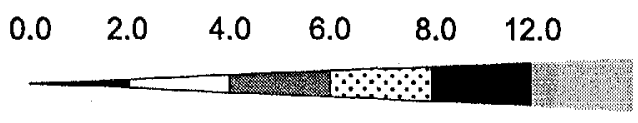

Wind Speed Class Boundaries (Meters/Second)

Windrose plot depicts the frequency of the direction from which the wind is blowing and the wind speeds 


\section{FIGURE 14. Seasonal Wind Roses for 1997}

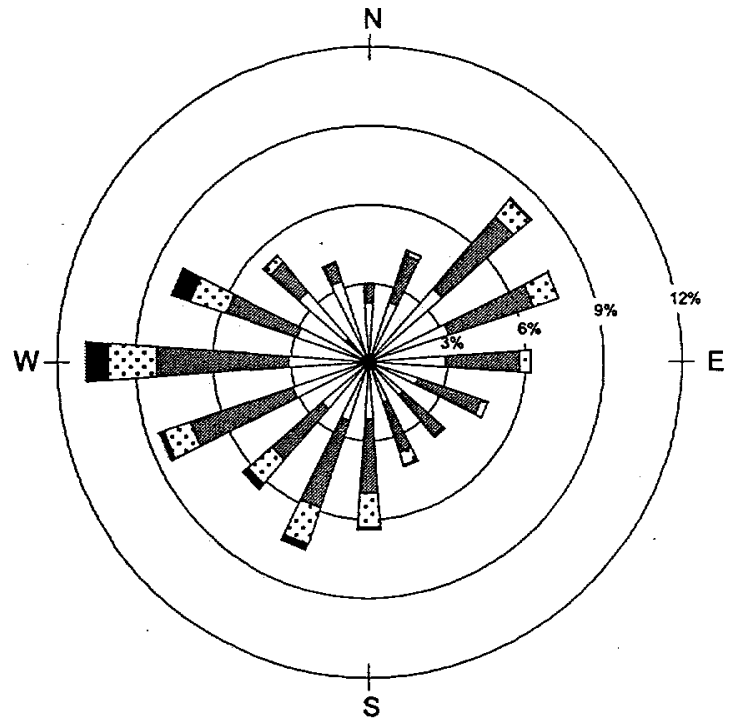

Winter 97

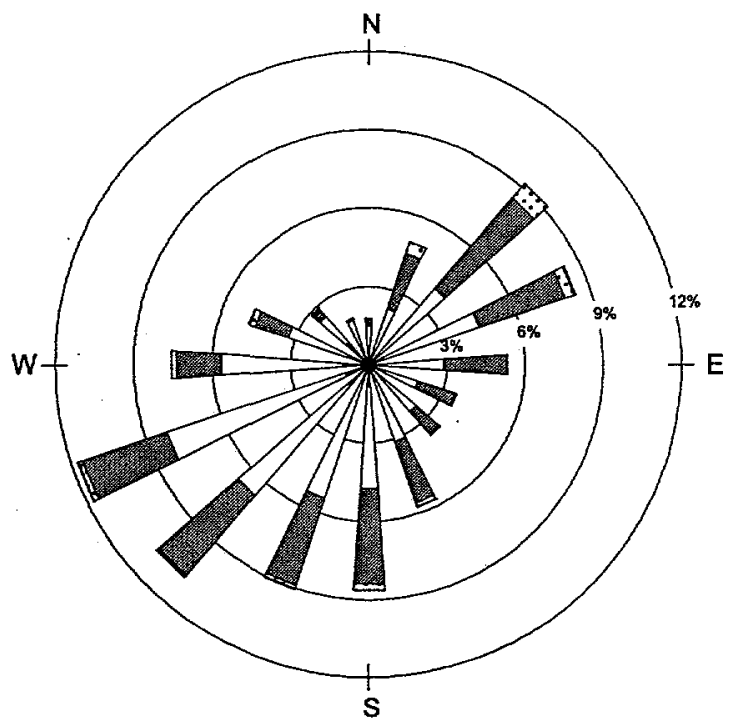

Summer 97

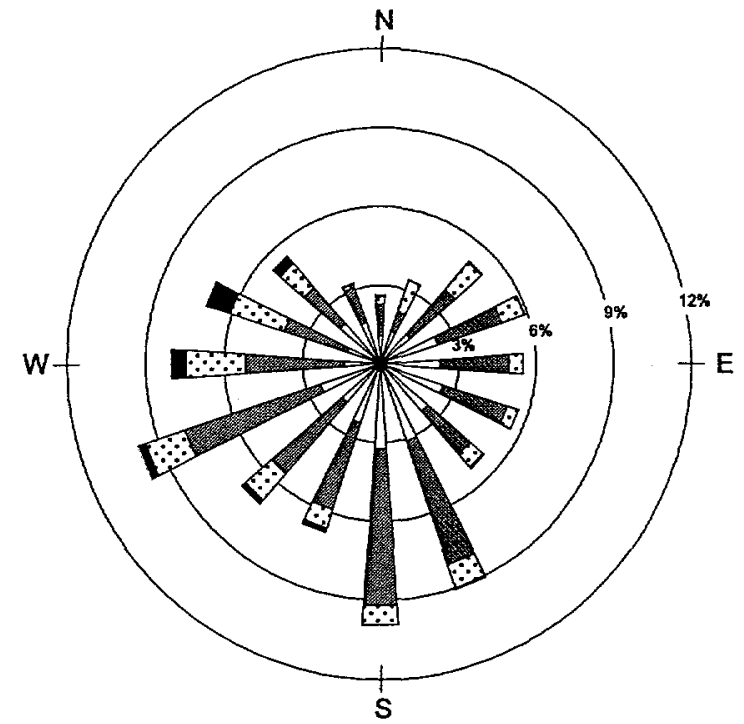

Spring 97

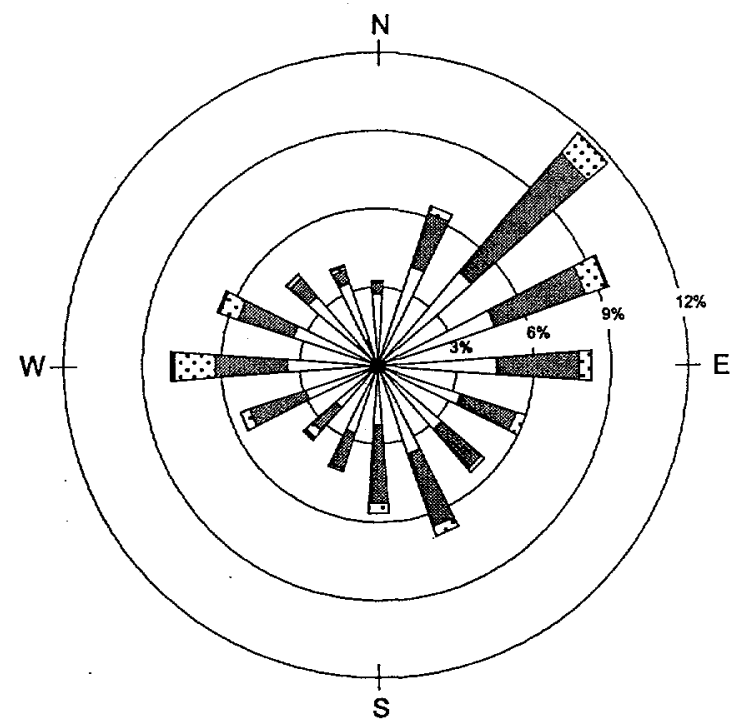

Fall 97

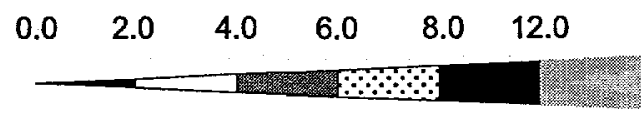

Wind Speed Class Boundaries (Meters/Second)

Windrose plot depicts the frequency of the direction from which the wind is blowing and the wind speeds 


\section{FIGURE 15. Seasonal Wind Roses,1992-96}

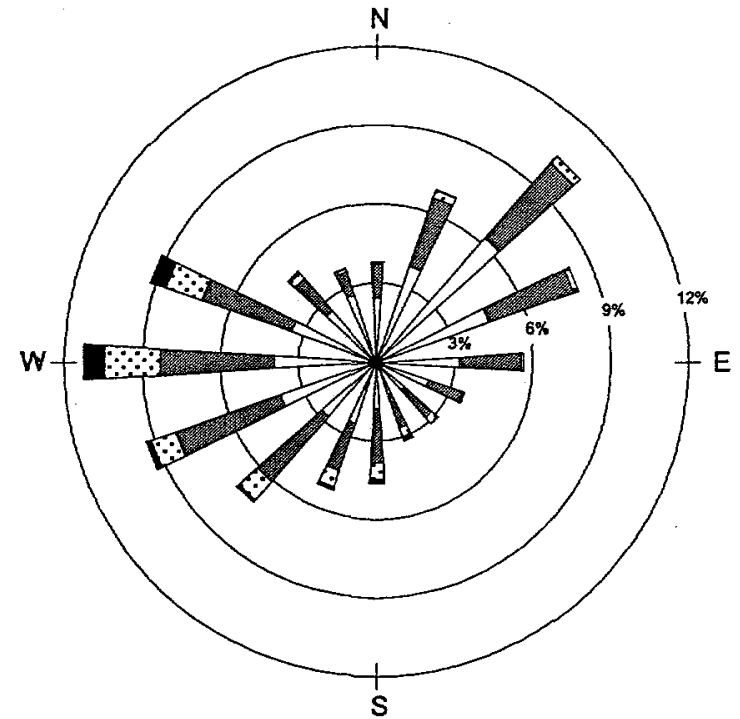

Winter 1992-96

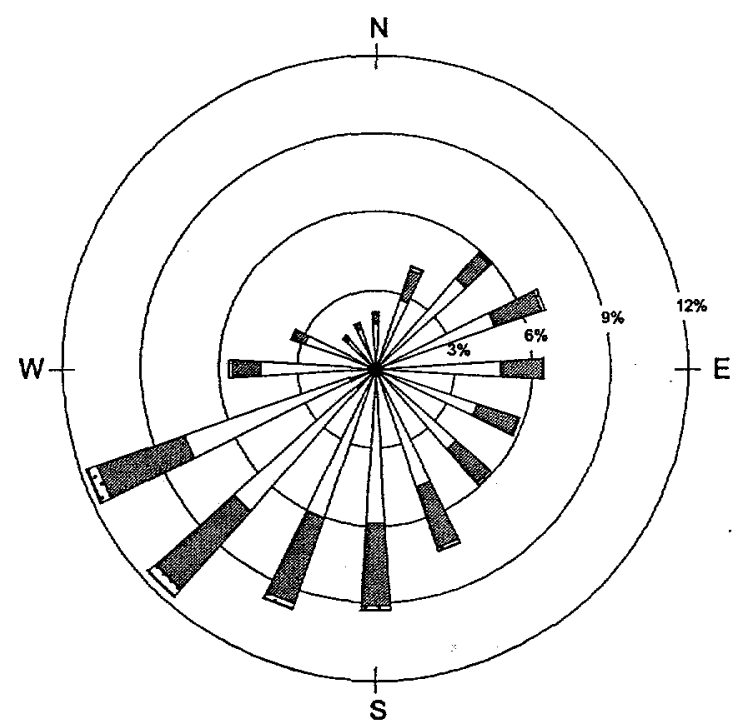

Summer 1992-96

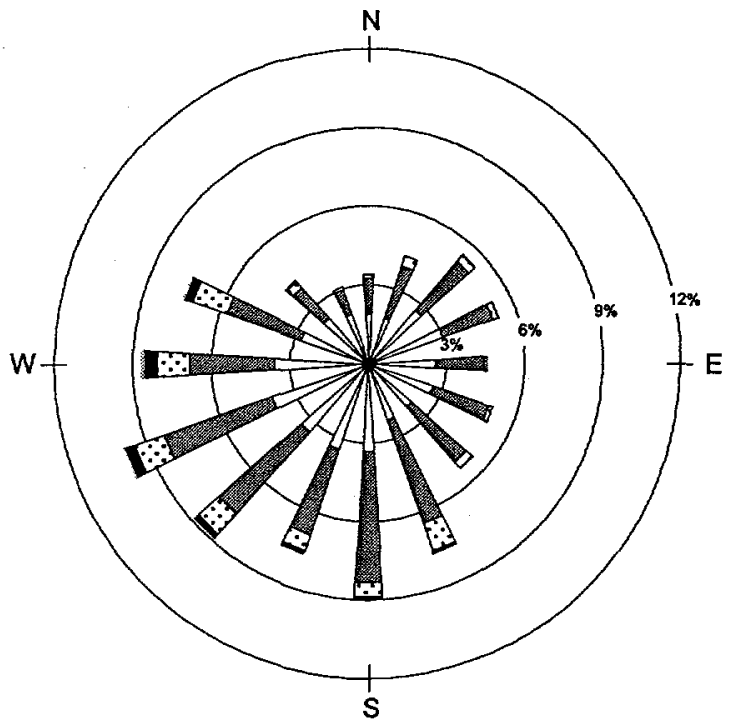

Spring 1992-96

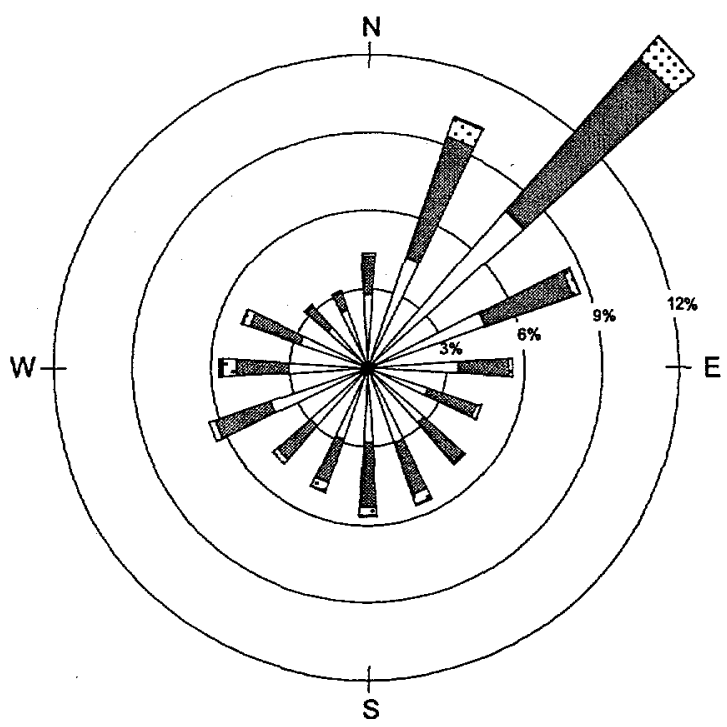

Fall 1992-96

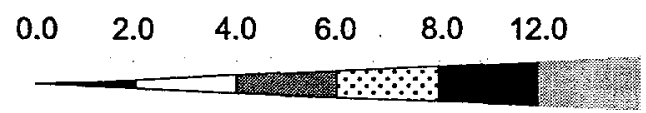

Wind Speed Class Boundaries

(Meters/Second)

Windrose plot depicts the frequency of the direction from which the wind is blowing and the wind speeds 
FIGURE 16. Annual Wind Rose Plots for A, C, D, and F Towers, 1997

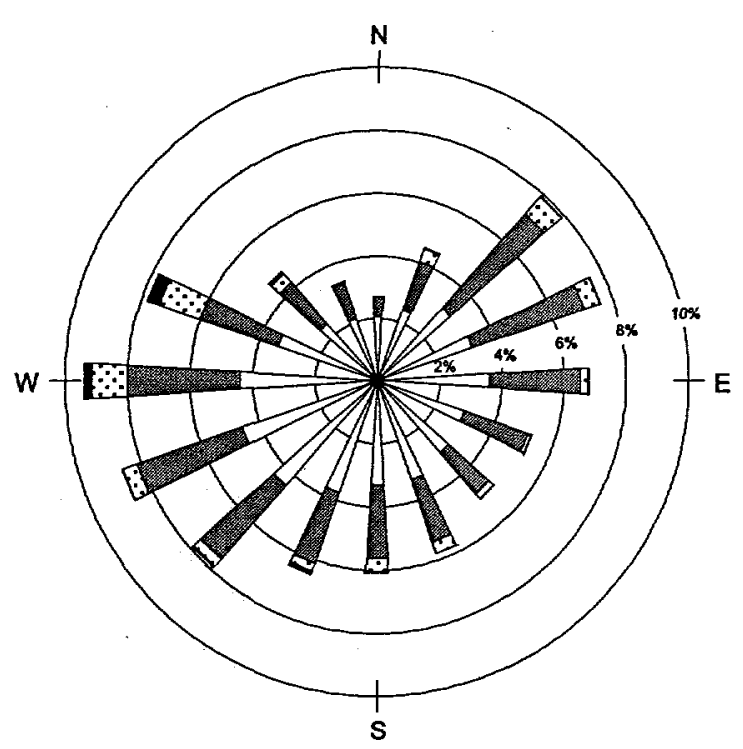

A Area Tower

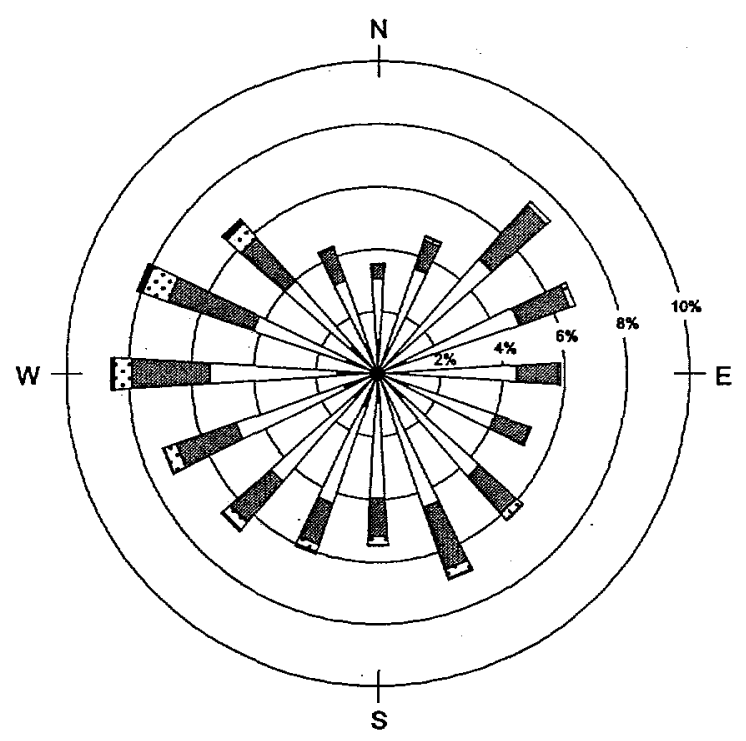

D Area Tower

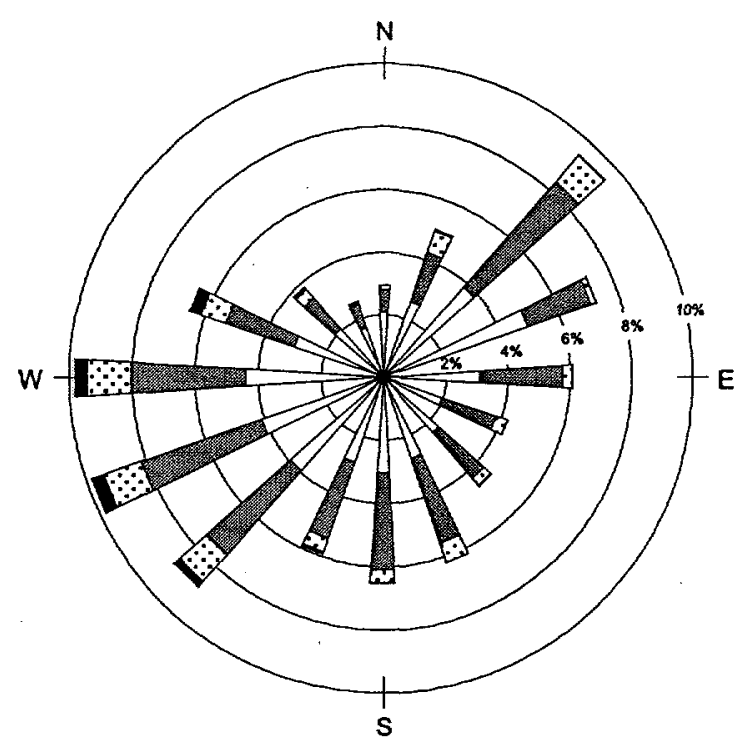

C Area Tower

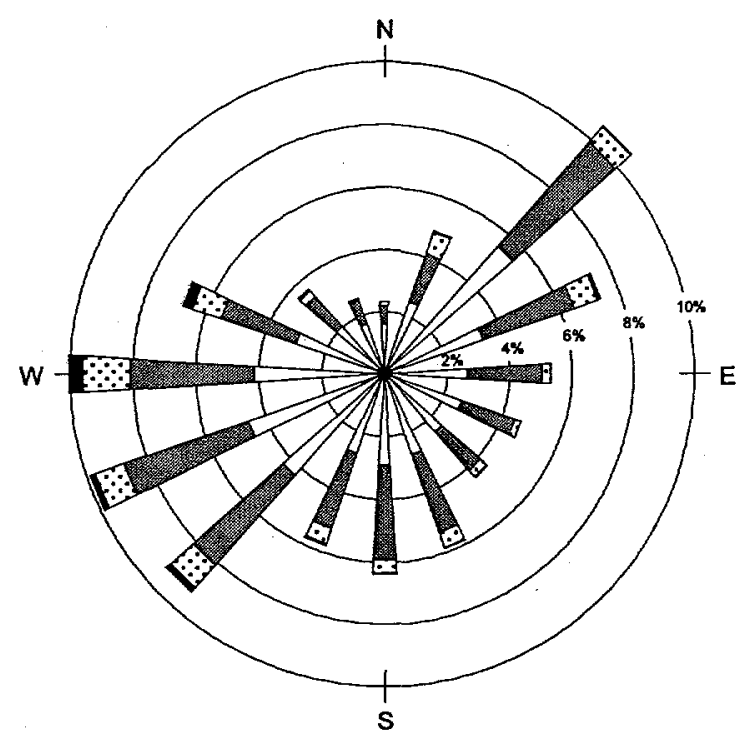

F Area Tower

$$
\begin{array}{llllll}
0.0 & 2.0 & 4.0 & 6.0 & 8.0 & 12.0 \\
\hline
\end{array}
$$

Wind Speed Class Boundaries (Meters/Second)

Windrose plot depicts the frequency of the direction from which the wind is blowing and the wind speeds 
FIGURE 17. Annual Wind Rose Plots for H, K, L, and P Towers, 1997

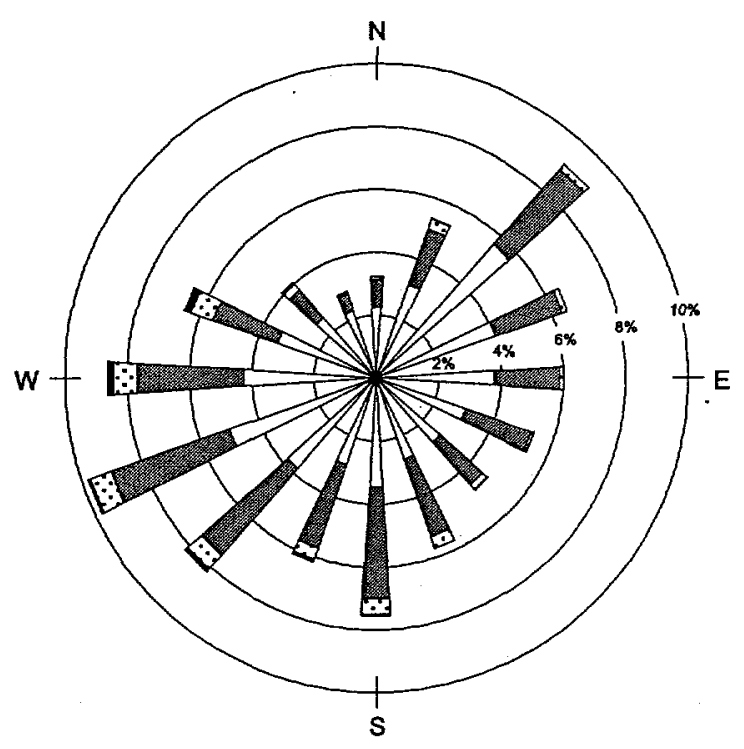

H Area Tower

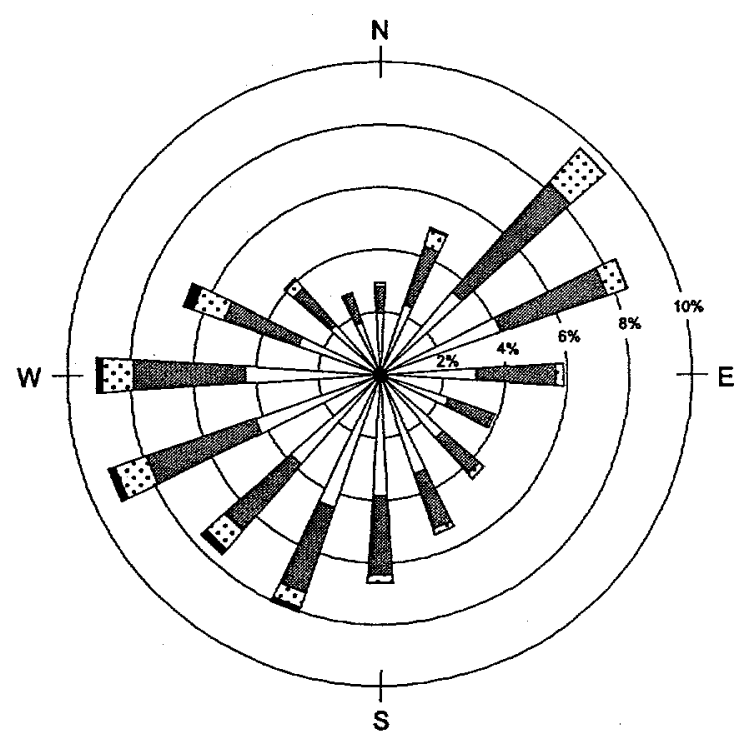

L Area Tower

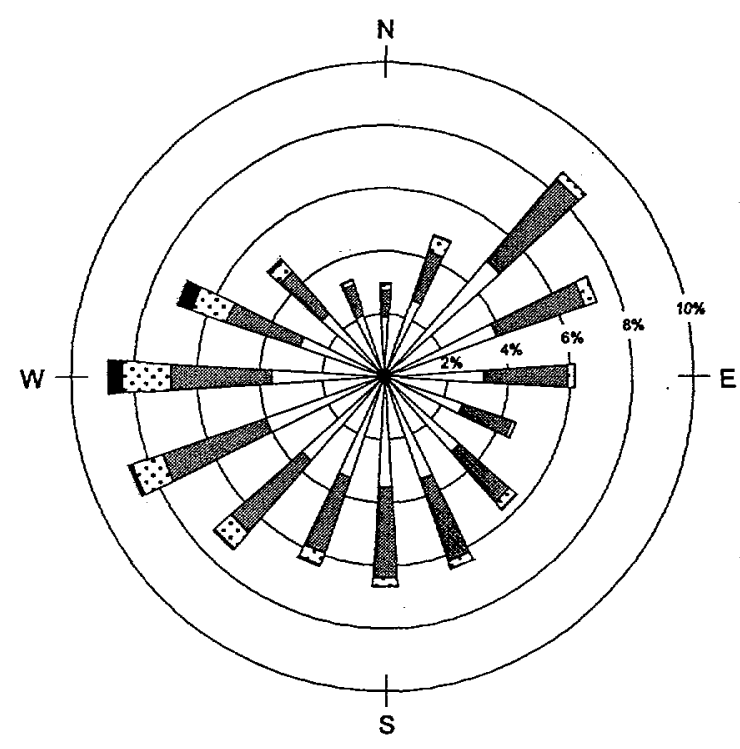

K Area Tower

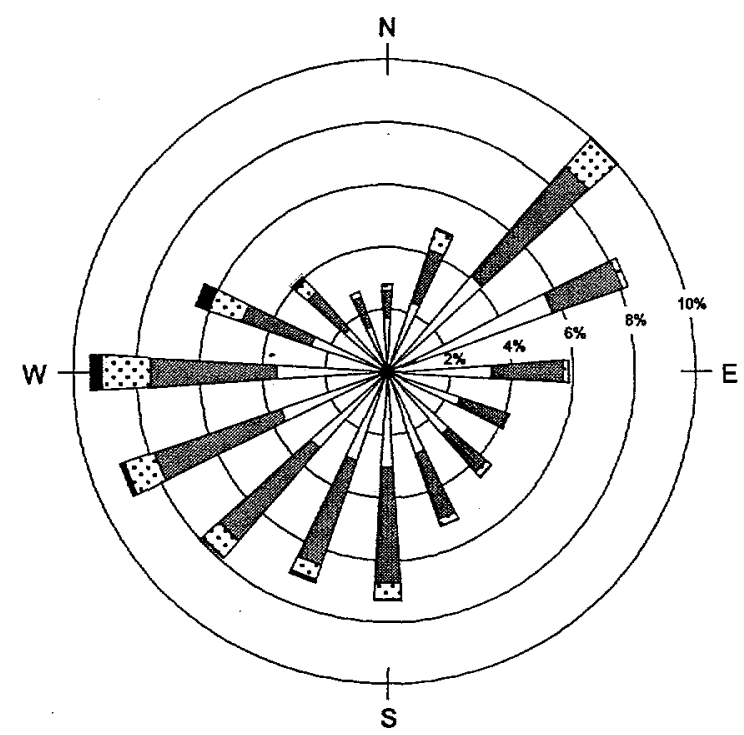

P Area Tower

$$
\begin{array}{llllll}
0.0 & 2.0 & 4.0 & 6.0 & 8.0 & 12.0 \\
\hline & & & & & 0
\end{array}
$$

Wind Speed Class Boundaries (Meters/Second)

Windrose plot depicts the frequency of the direction from which the wind is blowing and the wind speeds 
Figure 18. 1997 Daily Average Barometric Pressure

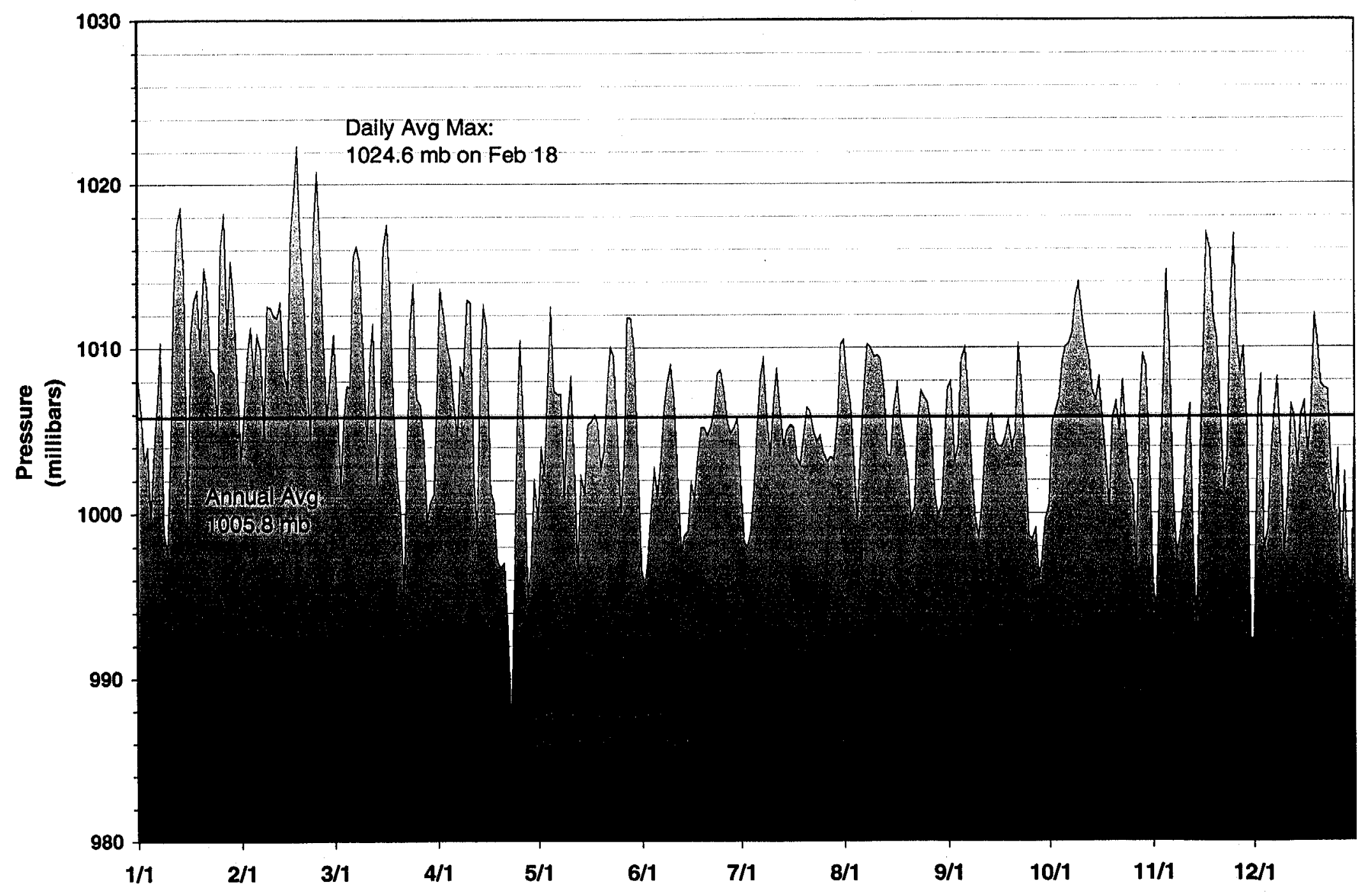




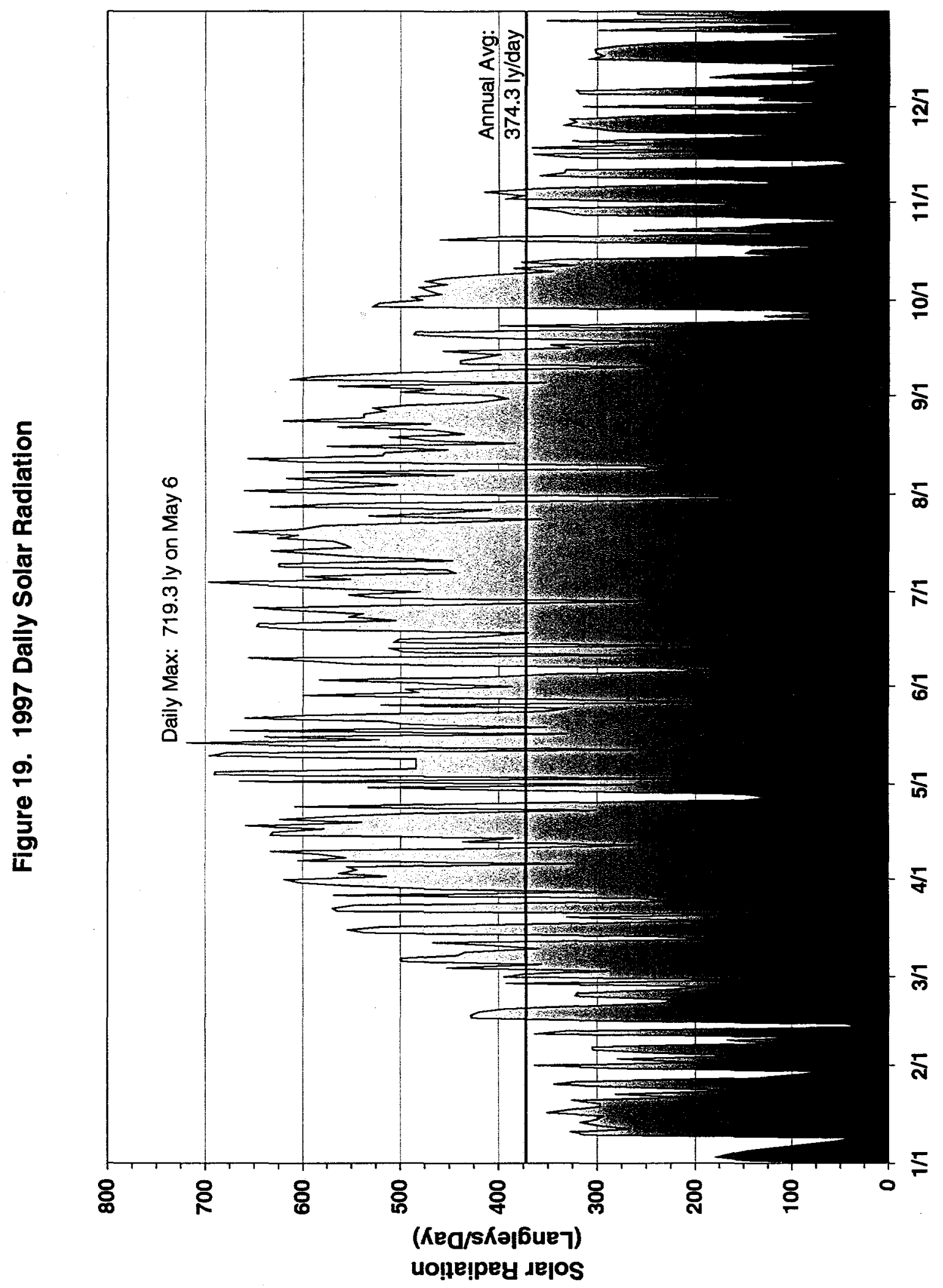

